\title{
Strain partitioning in host rock controls LREE release from allanite-(Ce) in subduction zones
}

\author{
Luca Corti $^{1}$, Davide Zanoni ${ }^{1}$, G. Diego Gatta ${ }^{1}$, Michele Zucali ${ }^{1,2}$
}

Running title: LREE in allanite controlled by strain

${ }^{1}$ Università degli Studi di Milano, Dipartimento di Scienze della Terra "Ardito Desio", Via Mangiagalli 34, 20133 Milano, Italy

${ }^{2}$ University of Houston, Department of Earth and Atmospheric Sciences, 3507, Cullen Blvd, Houston, Texas, USA

*Correspondig author e-mail: $\underline{\text { luca.corti@unimi.it }}$

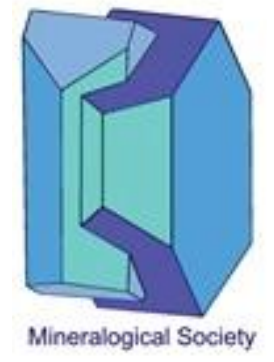

This is a 'preproof' accepted article for Mineralogical Magazine. This version may be subject to change during the production process. 


\begin{abstract}
Combined microstructural, mineral chemical, X-ray maps, and X-ray single-crystal diffraction analyses are used to reveal the rheological behaviour of individual grains of magmatic allanite relicts hosted in variably deformed metagranitoids at Lago della Vecchia (inner part of the SesiaLanzo Zone, Western Alps, Europe), which experienced high pressure and low temperature metamorphism during the Alpine subduction. X-ray single crystal diffraction shows that none of the allanite crystals, irrespective of the strain state of the host rock, record any evidence of plastic deformation (i.e., intracrystalline deformation), as indicated by the shape of the Bragg diffraction spots, the atomic site positions, and their displacement around the centre of gravity. On the contrary, strong plastic deformation affected matrix minerals, such as quartz, white mica, and feldspar of the hosting rocks, during the development of the Alpine eclogitic- and blueschist-facies metamorphism. Despite the strain-free atomic structures of allanite, different patterns of chemical zoning, as a function of strain accumulated in the rock matrix, are observed. Since allanite occurs in magmatic and metamorphic rocks and it is stable at high pressure and low temperature conditions, we infer that allanite could behave as one of the main carriers of light-rare-earth-elements into the mantle wedge during subduction of continental crust. In particular, the release of light-rare-earthelements from allanite, under high pressure conditions in subduction zones, is facilitated by high strain accumulated in the host rock.
\end{abstract}

\title{
Keywords
}

Mineral rheology; Sesia-Lanzo Zone; Strain partitioning; Single-crystal X-ray diffraction; LREE release; Chemical imaging.

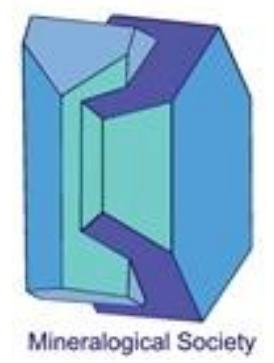

This is a 'preproof' accepted article for Mineralogical Magazine. This version may be subject to change during the production process. 


\section{Introduction}

Allanite, ideally ${ }^{A 1}(\mathrm{Ca})^{A 2}\left(\operatorname{LREE}^{3+}\right)^{M 1, M 2}(\mathrm{Al})_{2}{ }^{M 3}\left(\mathrm{Fe}^{2+}, \mathrm{Fe}^{3+}\right)\left(\mathrm{SiO}_{4}\right)\left(\mathrm{Si}_{2} \mathrm{O}_{7}\right) \mathrm{O}(\mathrm{OH})$, is a sorosilicate belonging to the epidote group minerals, with monoclinic symmetry and structure topology consistent with the space group $P 2{ }_{1} / m$ (Dollase, 1971; Catlos et al., 2000; Franz and Liebscher, 2004; Armbruster et al., 2006). With respect to the other epidotes, allanite preferentially incorporates a significant fraction of light-rare-earth-elements (LREE), and minor $\mathrm{Th}, \mathrm{U}, \mathrm{Sr}, \mathrm{Zr}$, and Cr into its structure (Deer et al., 1992; Catlos et al., 2000). The crystal structure is characterised by single silicate tetrahedra $\left(\mathrm{SiO}_{4}\right)$, double silicate tetrahedra $\left(\mathrm{Si}_{2} \mathrm{O}_{7}\right)$, and continuous chains of $M \mathrm{O}_{6}$ and $\mathrm{MO}_{4}(\mathrm{OH})_{2}$ octahedra parallel to the crystallographic $b$-axis (Dollase, 1971; Gieré and Sorensen, 2004; Armbruster et al., 2006).

The crucial role of allanite for metamorphic petrology is due to its wide compositional range and $P$ $T$ stability field. Allanite shows variable phase relations depending on $P-T$ conditions and on the reacting chemical system (e.g., Finger et al., 1998; Cox at al., 2003; Gregory et al., 2007): it occurs in igneous and metamorphic rocks (Franz et al., 1986; Moore and McStay, 1990; Sorensen, 1991; Schmidt and Thompson, 1996; Tribuzio et al., 1996; Liu et al., 1999; Carswell et al., 2000; CenkiTok et al., 2011; Cenki-Tok et al., 2014; Cliff et al., 2015; Manzotti et al., 2018) and it can incorporate up to about $60 \mathrm{wt} \%$ of the bulk rock LREE (especially Ce, La, and $\mathrm{Nd}$ ) as well as $\mathrm{Th}$ (Exeley, 1980; Brooks et al., 1981; Gromet and Silver, 1983; Tribuzio et al., 1996). Allanite competes with monazite, (LREE) $\mathrm{PO}_{4}$, one of the major carriers of LREE that can incorporate from 40 to $80 \mathrm{wt} \%$ of the LREE of the host rock (e.g., Bea, 1996; Finger et al., 1998). For this reason, the two minerals are considered the main potential carriers of LREE in the Earth's mantle through subduction (e.g., Hermann, 2002; Gieré and Sorensen, 2004; Hermann and Rubatto, 2009).

The $P-T$ stability fields of these LREE-bearing minerals are mostly controlled by temperature and Ca activity (e.g., Rasmussen et al., 2006; Boston et al., 2017; Engi, 2017). Allanite stability at hightemperature and high-pressure conditions increases in Ca-rich rocks (e.g., Janots et al., 2008; Kim 
et al., 2009; Radulescu et al., 2009). In metapelitic systems, monazite-to-allanite reaction develops between low grade and amphibolite-facies conditions (e.g., Smith and Barreiro, 1990; Wing et al., 2003; Tomkins and Pattison, 2007; Janots et al., 2007, 2008; Spear, 2010). In magmatic environments, the crystallisation temperature of these LREE-rich phases is similar (e.g., Lee and Silver, 1964; Casillas et al., 1995) and $\mathrm{Ca}$ content and $\mathrm{H}_{2} \mathrm{O}$ activity, during magma crystallisation, are the major parameters controlling allanite and monazite $P-T$ stability (e.g., Broska et al., 2000; Wing et al., 2003; Dini et al., 2004; Janots et al., 2008; Berger et al., 2009; Engi, 2017). In addition, allanite is characteristic of Ca-rich metaluminous granitoid rocks, whereas monazite is widespread in Ca-poor peraluminous granitoid rocks (e.g., Broska and Siman, 1998; Catlos et al., 2000).

Although the crystal chemistry and $P-T$ stability of allanite in natural systems have been thoroughly studied in the last decade (e.g., Wing et al., 2003; Janots et al., 2007, 2008; Gregory et al., 2012), little is known about the behaviour of its structural parameters during deformation and diffusion processes. Very recently, Gatta et al. (2019) described the compressional behaviour of allanite by in-situ single-crystal synchrotron X-ray diffraction with a diamond anvil cell. The experiments, conducted under hydrostatic conditions on natural allanite crystals, demonstrated that allanite preserves its crystallinity, along with an elastic compressional behaviour, at least up to $16 \mathrm{GPa}$ (at room temperature), without any $P$-induced phase transition within the $P$-range investigated. The thermodynamic elastic parameters have been obtained by an isothermal Birch-Murnaghan Equation of State fit to the $P-V$ data, and the evolution of the lattice parameters with $P$ showed a slight anisotropic compressional pattern (governed by the monoclinic symmetry of the structure). The main deformation mechanisms at the atomic scale were described on the basis of a series of structure refinements at different pressures. Comparing the (isothermal) compressional patterns with those obtained in previous studies, the effect of LREE on the elastic behaviour of epidotegroup minerals was inferred (Gatta et al., 2019). 
Recent works reported contrasting chemical and physical behaviours for allanite, preserving its primary chemical and isotopic fingerprint in crystals hosted in shear zones within eclogitised metagranitoid (e.g., Monte Mucrone, Western Austroalpine domain), suggesting a high shielding property due to high Young's modulus and low diffusion rates (Cenki-Tok et al., 2011). However, in this last work, LREE were not considered as the focus was on chemical elements used for geochronology. Conversely, allanite grown during shearing and metamorphism appears to have higher diffusion rate and lower Young's modulus (e.g., Dabie Shan; Liu et al., 1999; Monte Bianco, External Crystalline Massifs domain; Cenki-Tok et al., 2014; Sesia-Lanzo Zone, Regis et al., 2014).

Given these contradictory results, our aim in the present study is to investigate structural parameters, chemical compositions, and texture patterns of natural allanite-(Ce) crystals from the Lago della Vecchia metagranitoids in the Sesia-Lanzo Zone, Western Alps, in order to: 1) describe any potential crystal structure and mineral chemistry variation in response to the different conditions of the surrounding plastically deformed matrix during strain partitioning, and 2) estimate the LREE fraction released from allanite-(Ce) as a function of the accumulated strain in the host rocks. Allanite-(Ce) crystals were sampled in rock volumes that recorded different degree of fabric evolution and metamorphic reaction progress (Corti et al., 2017) during the development of the blueschist-facies dominant fabric (Corti et al., 2018). Hereafter, mineral abbreviations are used according to Whitney and Evans (2010), except for Wm (“white mica").

\section{Materials and methods}

\subsection{Geological outline}

The allanite-(Ce) crystals analysed in this study were sampled from the Lago della Vecchia metagranitoids, which are part of the Eclogitic Micaschists Complex of the Sesia-Lanzo Zone (EMC-SLZ), in the Austroalpine domain of the Western Alps (Fig. 1a). SLZ is a slice of continental crust that experienced $\mathrm{H} P$-LT conditions during the Alpine subduction (e.g., Compagnoni et al., 1977; Spalla et al., 1991; Zucali et al., 2002; Gosso et al., 2010; Roda et al., 2012; Giuntoli et al., 
2016; Roda et al., 2018; 2019). Metagranitoids occur as metre- to kilometre-sized bodies in tectonic contact with micaschists and gneisses (Corti et al., 2017). They spectacularly preserve magmatic textures and igneous minerals, within metre to decametre domains. These domains are only weakly affected by superposed Alpine tectonometamorphic imprints developed under eclogite- and blueschist-facies conditions (Zucali, 2011; Corti et al., 2018). The multiscale structural analysis and geothermobarometric estimates allow inference of the tectono-metamorphic evolution of the Lago della Vecchia metagranitoids (Corti et al., 2017; 2018). Pre-Alpine M0 magmatic stage consists of magmatic textures and igneous relicts in coronitic domains and allanite-(Ce) crystals in all-strain domains $\left(P=0.46 \pm 0.15 \mathrm{GPa} ; T=710 \pm 19^{\circ} \mathrm{C}\right)$. The first Alpine stage is $\mathrm{D} 1$ that developed the $\mathrm{S} 1$ foliation at $P=2.23 \pm 0.18 \mathrm{GPa}$ and $T=537 \pm 43{ }^{\circ} \mathrm{C}$, under eclogitic-facies conditions. S1 is locally preserved only in metabasite boudins within metagranitoids. D1 structures were transposed and obliterated by D2 stage that developed the pervasive $\mathrm{S} 2$ foliation at $P=1.12 \pm 0.11 \mathrm{GPa}$ and $T=$ $477 \pm 39^{\circ} \mathrm{C}$, under retrograde blueschist-facies conditions that suggest thermal state compatible with oceanic subduction (Corti et al., 2018; Fig. 1c). S2 foliation wraps metabasite boudins and intersects meta-aplitic dykes in metagranitoids. D3 and D4 stages $\left(P=0.6 \pm 0.10 \mathrm{GPa} ; T=302 \pm 24{ }^{\circ} \mathrm{C}\right)$ consist of localised S3 foliation, shear zones, and open folds marked by greenschist-facies assemblages, D5 developed km-long brittle-to-ductile mylonitic shear zones at shallow crustal level (Corti et al., 2017, 2018). In contrast with most of EMC, where the dominant fabric developed under eclogiticfacies conditions (Zucali and Spalla, 2011; Corti et al., 2019; Zucali et al., 2020), the dominant fabric of the Lago della Vecchia metagranitoids developed under the D2 blueschist-facies conditions. In response to deformation partitioning, D2 produced low-strain domains (i.e., coronitic domain) that are wrapped by intermediate (i.e., tectonitic domain) and high (i.e., mylonitic domain) finite strain domains (Fig. 1b; e.g., Gosso et al., 2015; Corti et al., 2017). 


\subsection{Allanite sampling}

Six metagranitoid samples with allanite-(Ce) crystals were selected taking into account the D2 domains of degree of fabric evolution (DFE) (Fig. 1b), as defined by Corti et al. (2017). While in mylonitic domains the rock fabric is entirely related to the new metamorphic conditions, in tectonitic to coronitic domains relic fabrics and mineral associations are preserved. The contouring of such domains with homogeneous DFE is facilitated by integrating meso- and micro-scale structural analysis (i.e., Gosso et al., 2015). Estimation of DFE is based on the volumes occupied by different degrees of grain-scale reorganization during D2, which span from coronitic to mylonitic domains (Lardeaux and Spalla, 1990; Gosso et al., 2015) (planar fabric: coronitic: 0-20\%; tectonitic: 21-60\%; mylonitic: 61-100\%). Thus, two samples were chosen from coronitic (C1 and C2 samples), tectonic (T1 and T2 samples), and mylonitic (M1 and M2 samples) metagranitoids, respectively (Fig. 1b). Location of samples is shown in Fig. 1b and is indicated in the following analytical tables and figures.

\subsection{Methods}

The rock microstructures and the crystallochemical features of the allanite-(Ce) crystals in different D2 fabric domains have been investigated by (transmitted) polarised light microscopy, scanning electron microscopy in wavelength-dispersive mode (WDS-EMPA), and single-crystal X-ray diffraction.

Quantitative WDS chemical micro-analyses were obtained with a JEOL 8200 Super Probe system at the Earth Sciences Department, University of Milan, with operating conditions of $15 \mathrm{kV}$ and $5 \mathrm{nA}, 5 \mu \mathrm{m}$ beam diameter, and counting times of $30 \mathrm{~s}$ on the peaks and $10 \mathrm{~s}$ on the backgrounds. Natural and synthetic crystals were used as standards and the results were corrected for matrix effects using a ZAF routine (Armstrong and Buseck, 1975), set in the JEOL suite of programs. The standards used are synthetic phosphate (LREE; Jarosewich and Boatner, 1991), forsterite-154 (Mg), ilmenite-149 (Ti), thorium-oxide (Th), grossular (Al-Si-Ca), and fayalite-143 (Fe). Selected mineral 
chemical data for each strain domain are reported in Table 1. The chemical formula of allanite-(Ce) was calculated following the IMA procedure, based on $\Sigma(A+M+T)=8$ cations per formula unit (Armbruster et al., 2006). X-ray elemental maps (i.e., WDS system: Al, Si, Ce, Nd, Th; EDS system: $\mathrm{Mg}, \mathrm{La}, \mathrm{Pr}, \mathrm{Fe}, \mathrm{Ca}$ ) of one Aln crystal within each strain domain were acquired under 60 ms dwell time, $15 \mathrm{kV}$ accelerating voltage and a probe current of $100 \mathrm{nA}$. A step size of $0.40 \mu \mathrm{m}$ on both the orthogonal reference directions ( $x$ and $y$ ) was used for acquiring an image with a resolution of $625 \times 625$ pixels.

The Quantitative X-Ray Map Analyser (QXRMA; Ortolano et al., 2018) was used to classify rockforming minerals starting from an array of X-ray elemental maps and to quantify the chemical zoning of Aln crystals and their chemical and textural relationships with the surrounding rockmatrix (e.g., Ortolano et al., 2014b). The QXRMA first cycle is useful to distinguish mineral phases as well as to extrapolate their modal fractions by a multivariate statistical analysis that allowed the handling of the X-ray maps through the Principal Components Analysis (PCA) and the supervised Maximum Likelihood Classification (MLC; Ortolano et al., 2014a). The second cycle performs a deeper analysis of Aln crystals, identified during the first cycle, for detecting mineral zonation.

A series of sub-millimetric crystals of Aln from all strain domains were picked up for the singlecrystal X-ray diffraction investigation. In particular, three crystals from a coronitic allanite-(Ce), two from tectonitic, and one from mylonitic domain were used. Intensity data were collected with an Xcalibur-Oxford Diffraction diffractometer, equipped with CCD, using a graphitemonochromatised Mo- $K \alpha$ radiation, and operated at $50 \mathrm{kV}$ and $40 \mathrm{~mA}$. A combination of omega and phi scans was used to maximize the reciprocal space coverage and redundancy, fixing a scan width of $0.5^{\circ}$, an exposure time of $30 \mathrm{~s} /$ frame, and a crystal-detector distance of $80 \mathrm{~mm}$. The unitcell was found to be monoclinic for all the crystals, and absence conditions always compatible with the $P 2_{1} / m$ space group. Intensities from all the datasets were integrated and corrected for Lorentzpolarization (Lp) effects using the CrysAlis ${ }^{\mathrm{TM}}$ software. Correction for absorption was applied by 
the semi-empirical ABSPACK routine implemented in CrysAlis ${ }^{\mathrm{TM}}$. The anisotropic structure refinements were conducted using the software SHELXL97 (Sheldrick, 1997), starting from the structure model of Dollase (1971) and Bonazzi et al. (2009) in the space group $P 2{ }_{1} / m$. The atomic sites were modelled as follows: the $A 1$ and $A 2$ sites were modelled with a mixed $(\mathrm{Ca}+\mathrm{Ce}) \mathrm{X}$-ray scattering curve; the $M 1$ and $M 2$ octahedral sites as populated by $\mathrm{Al}$ only and the $M 3$ site as populated by $(\mathrm{Fe}+\mathrm{Al})$; the three independent tetrahedral sites (i.e., Si1, Si2 and Si3) were modelled as fully occupied by Si. The proton site was located in all the refinements. Convergence was rapidly achieved for all the refinements and no significant correlation was observed in the variancecovariance matrix of the refined parameters. Further details pertaining to the data collection strategy and structure refinements are reported in Table S1 and in CIFs, deposited as electronic supplementary material.

\section{Results}

\subsection{Microstructures}

The microstructural analysis (in optical microscopy) reveals that, in all strain domains, Aln occurs as mm-sized single crystals characterised by high birefringence and dark-brown (cores) to lightbrown (rims) pleochroism. The Aln crystals are surrounded by blueschist-facies metamorphic assemblages consisting of Czo rims, fine-grained aggregates of $\mathrm{Wm}+\mathrm{Pl}+\mathrm{Ep}$, and large crystals or aggregates of Qz. The photolith of the analysed metagranitoids consists of a granodiorite (Figs 2a and $2 \mathrm{~b}$ ), according to the bulk-rock chemistry estimated on modal mineral content and mineral chemistry (data in Corti et al., 2018).

Coronitic domains are medium- to coarse-grained rocks showing a well-preserved magmatic texture with igneous mineral relics only partially replaced by Alpine metamorphic assemblages (Table 2). These domains are (volumetrically) constituted by Qz (20-25\%), Pl (15-20\%), Kfs (10-15\%), Wm (10\%), Grt (10\%), Ep (7-10\%), Aln (5\%), \pm Amp (<5\%), and \pm Opq $(<5 \%)$. The igneous minerals such as Bt, Kfs, and Aln constitute $\approx 20-30 \%$ of the rock volume. Tectonitic domains consist of 
fine- to medium-grained rocks that contain Qz (30-40\%), Wm (15-20\%), Ep (15-20\%), Grt (5\%), Amp (5\%), Kfs (5\%), and Aln (3\%). These domains mostly show a well-developed foliation marked by shape-preferred orientation (SPO) of Qz and aggregates of Wm and Ep (Table 2). Mylonitic domains consist of fine-grained rocks showing a millimetre-spaced foliation defined by SPO of Wm, Ep, and Amp that wraps porphyroblasts of Grt and porphyroclasts of Kfs (Table 2). These rocks are constituted by Qz (40-50\%), Wm (15-20\%), Ep (12-15\%), Grt (5-7\%), Amp (5$10 \%)$, and $\mathrm{Aln}(<5 \%)$. In tectonitic and mylonitic domains, igneous $\mathrm{Kfs}(<5 \%)$ and $\mathrm{Aln}(<5 \%)$ constitute less than $10 \%$ of the rock volume and the new planar fabrics largely overprint igneous textures.

In coronitic domains, Aln occurs in well-formed 50-200 $\mu$ m-sized crystals (Fig. 3a), surrounded by Czo, Wm, and Ep (Fig. 3b). In tectonitic domains, the Aln crystal size is similar but the corona of Czo is more developed (Fig. 3c) and is wrapped by the dominant foliation (Fig. 3d). The microstructural analysis of evolution of superposed fabrics and related mineral assemblages suggests that Aln pre-dates the Alpine metamorphism and it is interpreted as a magmatic relict (Table 2). In mylonitic domains, the dominant $\mathrm{S} 2$ is a spaced and discontinuous foliation marked by microlithons of Qz and Fsp, and films of Wm, Ep, and Czo, which wrap millimetre-sized Aln porphyroclasts. The Aln crystals are aligned and often boudinated along S2 (Fig. 3e), without evidences of plastic deformation (Table 2). In contrast, the matrix minerals, such as Qz, Wm, Fsp, Czo, and Ep show evidence of plastic deformation and grain-size reduction (Fig. 3f). Crystal plasticity and grain reduction increase with DFE (e.g., Punturo et al., 2014), making the solid-state flow itself more efficient in further decreasing the matrix grain size; these processes all contribute to increase the rheology contrast of matrix minerals against stiffer phase forming porphyroclasts. The lack of plastic deformation suggests that Aln porphyroclasts experienced passive rotation during the development of S2 that results into SPO, which is more evident the higher is the total 
strain accumulated by host rock. Details on petrography and microstructures of metagranitoids are in Corti et al. $(2017,2018)$.

\subsection{Chemical imaging}

X-ray elemental mapping of the selected Aln crystals from the different strain domains reveals evident mineral zonation, especially related to the relative concentration of $\mathrm{Ca}, \mathrm{Ce}, \mathrm{Fe}$, and $\mathrm{Th}$ (Fig. 4). Increase in the proportion of $\mathrm{Ca}$ and decrease in the proportions of $\mathrm{Fe}, \mathrm{Ce}$, and $\mathrm{Th}$ towards the Aln rim (Fig. 4 and Table 1) are consistent with the substitution mechanisms relating Aln and Czo: $\mathrm{REE}^{3+}+\mathrm{M}^{2+} \rightarrow \mathrm{Ca}^{2+}+\mathrm{M}^{3+}$ (Armbruster et al., 2006).

The QXRMA procedure is a powerful tool for quantitatively defining the spatial distribution of Aln chemical zoning and to discuss this chemical variation in relation with the strain domains. The first cycle of QXRMA analysis allows the mineral classification within the three microdomains. The classified pixels are $99.98 \%, 99.87 \%$, and $99.93 \%$ for the images related to coronitic, tectonitic, and mylonitic domains, respectively. The identified mineral phases are Aln, Czo, Ep, Wm, and Qz (Fig. 5), which correspond to the pre-Alpine Aln porphyroclasts, and Alpine Czo, Ep, Wm, and Qz blueschist-facies mineral associations.

The second cycle of QXRMA analysis reveals three major chemical zones in Aln: Aln1, Aln2, and Aln3 as shown in Figure 5a. In general, Aln 1 constitutes the core and Aln3 the rim in the crystals from all strain domains, though the relative proportion of Aln1, Aln2, and Aln3 may change (Fig. 5a). These three zonations are defined by the relative variation of $\mathrm{LREE}-\mathrm{Fe}^{2+} v s . \mathrm{Al}-\mathrm{Fe}^{3+}-\mathrm{Ca}$ concentrations, which is characterised by LREE-Fe ${ }^{2+}$ depletion and Al-Ca enrichment from Aln1 to Aln3 (Fig. 5b; Table 1). The LREE partitioning shows as the concentric zonation in coronitic domain is given by Ce-rich core and $\mathrm{Th} / \mathrm{Nd}$-rich rim, whereas the chemical zoning in tectonitic and mylonitic domains is elongated according to the S2 foliation. RGB X-ray map analysis reveals differences in chemical pattern of LREE elements, such as $\mathrm{Ce}, \mathrm{Nd}$, Th, in relation with the strain domains (Fig. 5b). These elements generate patchwork and en-echelon-like chemical zonation in 
tectonite and mylonite domains, respectively (Fig. 5b). En-echelon-like chemical zonation forms an angle of about $30^{\circ}$ with respect to $\mathrm{S} 2$ in rock matrix.

\subsection{Mineral Chemistry}

Aln crystals show homogeneous chemical variation from core to rim (LREE depletion and $\mathrm{Al}$ enrichment from Aln1 to Aln3; Fig. 6). Regardless the strain domain, allanite-(Ce) crystals show Ce depletion and $\mathrm{Nd}$ enrichment from Aln1 to Aln3 (Fig. 7). The chemical zoning is highlighted by the $\mathrm{Ce} / \mathrm{LREE}$ and $\mathrm{Ca} / \mathrm{LREE}$ ratios $v$ s. Al partitioning, and follow a linear trend of LREE depletion and $\mathrm{Al}$ enrichment from Aln1 to Aln3 (Figs 8a and 8b).

Allanite-(Ce) in coronitic and tectonitic domains displays a similar chemical pattern: Ce/LREEricher core (Fig. 8b) and a generally higher Al content than Aln in mylonitic domains. The lowest Ce/LREE values in all Aln zonations represent a common feature in mylonitic domains (Fig. 8b). In Aln3 from mylonitic domains, $\mathrm{Ca} / \mathrm{LREE}$ ratio shows the highest values, and this ratio in Aln3 progressively decreases in tectonitic and coronitic domains (Fig. 8a).

\subsection{Single crystal $\mathrm{X}$-ray diffraction}

As shown in Fig. 9, the X-ray diffraction patterns of the investigated crystals of allanite-(Ce), belonging to three different domains (i.e., coronitic $\mathrm{C} 1$, tectonitic $\mathrm{T} 1$ and mylonitic $\mathrm{M} 2$ ), show diffraction spots with approximately circular sections (max ellipticity ratio: 1.2:1) and similar fullwidth-at-half-maximum (FWHM), in turn similar (within $3 \sigma$ ) to those of unstrained gem-quality epidote crystals (previous studies by Gatta et al. 2010, 2011a, and using the same experimental setup here used). In other words, there is no evidence of potential textured patterns (on some specific crystallographic planes) and this is irrespective of the different strain domains of the sample (i.e., coronite, tectonite, mylonite).

The structure refinements based on the six data sets (i.e., \#3.10, \#3.11 and \#1.10 from the coronitic C1, \#5.3 and \#5.5 from the tectonitic T1, and \#8.1 from mylonitic M2 domains; see the CIFs and 
Table S1) are of similar quality, as shown by the values of the statistical parameters: $R_{\mathrm{int}} \approx 0.03-$ $0.04, R(F)_{\mathrm{obs}} \approx 0.03-0.04, w R\left(F^{2}\right)_{\mathrm{obs}} \approx 0.05-0.06$ (see the CIFs and Table S1). All the leastsquares refinements produce similar atomic coordinates (and therefore similar bond distances and angles of the coordination polyhedra) along with their anisotropic displacement parameters (excluding the proton site, which was modelled isotropically). In the structure refinements of this study, the anisotropic displacement factor exponent of each atomic site is modelled on the Gaussian approximation, with the form: $-2 \pi^{2}\left[\left(h a^{*}\right)^{2} U^{11}+\left(k b^{*}\right)^{2} U^{22} \ldots+2 h k a^{*} b^{*} U^{12}\right]$, according to Fischer and Tillmanns (1988). The individual atomic anisotropic displacement parameters may represent atomic motion or possible static displacive disorder. When a given crystallographic site is populated by a multi-elemental population, its anisotropic displacement parameter can be virtually pronounced in response to the different displacement of the elements from the centre of gravity. This could be the case of allanite-(Ce), in which (at least) $A 1, A 2$, and $M 3$ sites are affected by multi-elements site population. Despite that, the refined atomic displacement ellipsoids, pertaining to all the six structure refinements of this study, are all in line with those usually found in gem-quality unstrained crystals (i.e., with a modest ratio of the longest and shortest root-mean-square components of the ellipsoids, < 1.7-2.0) and, in turn, very similar (per each relative crystallographic site) among the six refinements. For example, Fig. 10 shows the refined structure model based on the X-ray intensity data generated by the crystal \#8.1, belonging to the mylonitic domain M2 (i.e., the most strained one), with atomic displacement probability factor at $99 \%$.

\section{Discussions}

\subsection{Crystallography constrains}

As observed by Gatta et al. (2009) for strained kyanite crystals from the Eclogitic Micaschists Complex of the Sesia Lanzo Zone (EMC-SLZ), the X-ray single-crystal diffraction experiments can provide evidence of plastic deformation at two different levels, which are mutually related: $i$ ) the first reflects the 3-dimensional periodic arrangement of the atomic sites, and it is represented by 
shape and size of the Bragg diffraction spots, $i i)$ the second reflects the displacement from the centre of gravity of any given atomic site, and it is represented by magnitude and orientation of the displacement ellipsoid produced by the structure refinement. On the whole, Gatta et al. (2009) ascribed the anomalous magnitude (and orientation) of the displacement parameters (i.e., with an extremely high ratio of the longest and shortest root-mean-square components of the ellipsoids, up to 4.0) and the features of the diffraction pattern (elliptical shape of the Bragg spots on the $(h 0 l)^{*}$ plane with significantly relevant ellipticity ratio, up to 3:1, and a severe bending) of Ky to two potentially combined effects: $i$ ) crystals were actually composed by several blocks; $i$ ) crystals were affected by pervasive residual strain, as a result of plastic deformations and re-crystallization (with at least two stages of growth) during the long-lived tectono-metamorphic evolution.

Aln crystals of this study do not show any evidence of pervasive residual strain ascribable to a plastic deformation: 1) the single-crystal X-ray diffraction patterns are those of clearly unstrained crystals, with Bragg spots of almost circular section (ellipticity ratio up to 1.2:1) and FWHM comparable (within $3 \sigma$ ) to that of gem-quality unstrained epidote crystals; 2 ) the structure refinements provide structural models virtually identical to those of other (unstrained) allanite reported in the literature, in particular with atomic displacement parameters which are, in shape and magnitude, comparable to those previously reported.

The different behaviour of Aln and Ky cannot simplistically be ascribed to the different general symmetry of the structures (as symmetry governs the deformation mechanisms): Aln and Ky are both low-symmetry minerals (Aln is monoclinic, Ky is triclinic), with high-degrees of freedom of deformation, though the lower symmetry of kyanite permits more degrees of deformation.

However, kyanite and allanite show a remarkable contrasting physical behaviour in relation with the incremental deformation, even under similar $P / T$ ratios (e.g., Delleani et al., 2012; Corti et al., 2018) and hosting rock-matrix (in both cases Qz-rich). The response to the tectono-metamorphic conditions appears not to be simply related to the bulk compressibility: the isothermal bulk modulus 
(valid at room conditions, $K_{\mathrm{P} 0, \mathrm{~T} 0}$ ) of kyanite is $K_{\mathrm{P} 0, \mathrm{~T} 0}=190-200 \mathrm{GPa}$ (Liu et al., 2009), that of allanite is $K_{\mathrm{P} 0, \mathrm{~T} 0}=131(4) \mathrm{GPa}$ (Gatta et al., 2019); therefore, kyanite is drastically stiffer than allanite. In addition, the combined effect of $P$ and $T$ could play an important role: in situ experiments at high $T$ (and room $P$ ) proved that Ky experiences a remarkable $T$-induced expansion $\left[\alpha_{0}(V) \approx 7.4 \cdot 10^{-3} \mathrm{~K}^{-1}\right.$, Gatta et al. 2006] if compared to epidote-group minerals $\left[\alpha_{0}(V) \approx 5.1 \cdot 10^{-5} \mathrm{~K}^{-1}\right.$, Gatta et al. 2011b]. In other words, Ky is stiffer than allanite (or epidotes, in general) at room $T$, but it is pronouncedly more expandable in response to the applied high $T$. The competing effects generating by $P$ and $T$ would explain the different behaviour of the two minerals.

As the plastic behaviour is expected to be governed by the crystal structure, the further question is: how does isomorphic substitution influence plastic response among the (isostructural) epidotegroup minerals? The answer to this question is not trivial. The recent study of Gatta et al. (2019) on the elastic behaviour of allanite under compressional regime, which provided also a comparative analysis among the epidote-group minerals (based on previous data by Gatta et al., 2011b, and Qin et al., 2016), reported that the compressional patterns among this group of minerals are different at a significant level, in terms of bulk compression and elastic anisotropy, though not drastically. The following isothermal bulk moduli were obtained: $K_{\mathrm{P} 0, \mathrm{~T} 0}=131(4) \mathrm{GPa}$ for allanite, $K_{\mathrm{P} 0, \mathrm{~T} 0}=111(3) \mathrm{GPa}$ for epidote with $0.74 \mathrm{Fe}$ a.p.f.u. and $K_{\mathrm{P} 0, \mathrm{~T} 0}=115(2) \mathrm{GPa}$ for epidote with $0.79 \mathrm{Fe}^{3+}$ a.p.f.u., and $K_{\mathrm{P} 0, \mathrm{~T} 0}=142(3) \mathrm{GPa}$ for clinozoisite with $0.40 \mathrm{Fe}^{3+}$ a.p.f.u. Epidote is the least stiff, clinozoisite the stiffest, and allanite is intermediate in stiffness between the two. Among the aforementioned epidote-group minerals, there are at least three variables that can generate the different compressional behavior: the $\mathrm{Fe}^{3+} v s$. Al substitution at the $M 3$ site (epidote, clinozoisite, allanite), the occurrence of $\mathrm{Fe}^{2+}$ at $M 3$ in allanite, and the $\mathrm{Ca}^{2+} v s$. LREE substitution at the $A 1$ and $A 2$ sites in allanite.

On the basis of the structural homology among the aforementioned minerals, which governs their "similar" compressional behavior, we cannot exclude that even the other epidote-group species 
would experience a similar plastic behavior as that of allanite under the same tectono-metamorphic conditions of the samples here investigated.

\subsection{LREE released $v s$. host rock matrix total strain}

The multidisciplinary approach of this study reveals that Aln can be remarkably resistant to deformation and metamorphism under cold subduction thermal state (see Corti et al., 2018). Under these conditions, Aln crystals do not show evidence of intra-crystalline plastic deformation from micro- to atomic-scale along strain gradients. Aln behaves as a "rigid" object, at a first approximation, in a weak rock matrix (metagranitoids with modal amount of $\mathrm{Qz}+\mathrm{Wm}>60 \%$; Table 2) and it is characterised by high mechanical strength and it is reluctant to recrystallize during polyphasic tectono-metamorphic history. Even in mylonitic domains, Aln is rigid because deformation is accommodated by the recrystallization of Qz and Pl grains and crystal folding (e.g., Wm). In addition, it should be considered that the positive correlation of DFE and DRP (Corti et al., 2017) implies that mylonitic rocks are enriched in weak mineral phases, such as Wm and Qz. In this context, the solid-state flow becomes easier as the deformation progresses. Deformation is thus responsible for a progressive interconnection of weak mineral phases (e.g., Goncalves et al., 2012) that defines eventually a new foliation, which makes easier the solid-flow itself. Thus, under blueschist-facies conditions, Aln porphyroclasts can behave more rigidly, with respect to rock matrix, in mylonite than in tectonitic and coronitic domains. Therefore, the joint effect of deformation and metamorphism is responsible for an increase of competence contrast (i.e., viscosity) between stiff and weak materials (Ramberg, 1955), that is between Aln porphyroclasts and host rock matrix. Indeed, we found boudinaged Aln porphyroclasts only in mylonitic rocks.

Quantitative mineral chemical analysis and chemical imaging procedure were performed to decipher the chemical features of the Aln zoning in relation to the rock-matrix strain accumulation. The Aln chemical zoning is mostly defined by the $\mathrm{Ca}$ / and Ce/LREE ratio. The high $\mathrm{Ca}$ fraction in the Aln3 sample may be due to a more progressed metamorphic transformation, especially in 
mylonitic domains. Despite a general Al depletion in the mylonitic domains, the analysed Aln crystals show a similar LREE content within the inner zoning (i.e., Aln1, Aln2). The chemical variation became appreciable in the outermost zoning (i.e., Aln3) and in mylonitic domains, the Aln3 shows even lower LREE contents than Aln3 in coronitic and tectonitic domains (Figs. 8a and $8 b)$.

The QXRMA procedure reveals that elements such as $\mathrm{Ce}, \mathrm{Nd}$, and Th build up patchwork and enechelon-like re-arrangement of Aln zoning in tectonitic and mylonitic domains, respectively (Fig. 5). These chemical features might, therefore, be the effect of the strong strain partitioning between Aln and the matrix minerals at $\mathrm{H} P$-LT conditions during subsequent tectono-metamorphic stages and the interplay of strain, temperature, pressure, and fluids in promoting ion intracrystalline mobility.

Allanite is known as one of the main potential carriers of LREE in the mantle wedge (e.g., Hermann, 2002; Gieré and Sorensen, 2004; Hermann and Rubatto, 2009), because of high shielding property during subduction processes (Cenki-Tok et al., 2011). Combining the Ca/LREE ratio of the Aln crystals with the DFE rock-matrix estimation of each analysed sample (Table 2; Corti et al., 2017), it is possible to estimate the LREE release in relation with the strain accumulated by the rock-matrix during D2 (responsible for the S2 dominant foliation) tectono-metamorphic stage (Fig. 11). The LREE released during the exhumation in the subduction mantle wedge for the six analysed Aln crystals was estimated through two parameters in relationship with the DFE (Fig. 11). The first is the difference between $\mathrm{Ca} / \mathrm{LREE}$ ratio in $\mathrm{Aln} 1$ and $\mathrm{Aln} 3$, normalised to the sum of $\mathrm{Ca} / \mathrm{LREE}$ ratio in the three zoning of a single grain. Figure 11a show a well-defined linear regression $(y=0.2 x+$ 20, with $R^{2}=0.97$ ) between the normalised Ca/LREE ratio and the strain accumulation in the rock matrix. The second parameter is the difference between the LREE contents in Aln1 and Aln3, normalised to the sum of LREE in the three zoning of a single grain (Fig. 11b), and it reflects a LREE loss parameter. The relation between LREE variations and DFE is characterised by an 
exponential regression $\left(y=0.96 e^{0.06 x}\right.$, with $\left.R^{2}=0.96\right)$. These two correlations allow the quantification of the amount of LREE released from Aln grains in the three strain domains. In tectonite and mylonite, the amount of LREE remaining in Aln3 is insufficient for it to be allanite; instead Aln 3 is Czo, according to the IMA classification (Armbuster et al., 2006). We consider this composition type as a transition between Aln and Czo due to the loss of LREE resulting from deformation accumulated by rock matrix.

Our results show that Aln appears to be able to carry and release LREE under HP-LT conditions if the surrounding rock matrix accumulates high total strain and metamorphic transformation. Indeed, Aln in mylonitic rocks shows higher Ca/LREE and LREE loss parameters than Aln in tectonitic and coronitic domains (Figs 8a and 11). The diagrams in Fig. 11 show that from coronite to mylonite the increase of the two parameters is continuous, and by comparing Fig. 11 with Table 2 a positive correlation of these two parameters with the quantitative estimates of DFE is evident. Therefore, a LREE loss of 1-2\%, 15-38\%, and 72-88\% (Fig. 11b) and increase of Ca/LREE parameter of 2021\%, 28-30\%, and 34-38\% (Fig. 11a) are estimated for coronitic, tectonitic, and mylonitic domains, respectively. The two parameters increase from coronite to mylonite but with a linear and exponential trend for Ca/LREE and LREE loss, respectively. The high Ca/LREE and LREE loss parameters may be due to a more progressed metamorphic transformation facilitated by high strain accumulation in mylonitic domains. During mylonitic deformation, fluid may be driven more effectively into local low stress domains than during development of tectonitic and coronitic textures. For instance, these low stress domains are strain shadows around allanite prophyroclasts, and fluids coming in may leach away incompatible elements (i.e., LREE) from allanite.

\section{Conclusion}

This work shows that allanite-(Ce) enclosed in metagranitoids under subduction thermal state and blueschist-facies conditions do not record any plastic deformation regardless the total strain accumulated by the host rock. The plastic deformation is accommodated by the rock matrix 
minerals, such as quartz, feldspar, and white mica. The only evidence of deformation in allanite(Ce) is represented by brittle boudinage in mylonitic rocks. The deformation in the rock matrix appears to be responsible for the linear chemical zoning patterns in tectonite and mylonite crystals. The total strain accumulated by hosting rocks under HP-LT has also a strong control on LREE in allanite-(Ce). The release of LREE from allanite-(Ce) is indeed facilitated if high strain and metamorphic transformation is accumulated in the surrounding rock matrix (i.e., mylonitic shear zones). Therefore, strain is a fundamental parameter to provide subduction wedge with LREE.

\section{Acknowledgment}

Peter Leverett, Geoff Bromiley, Gaetano Ortolano, and the Associate Editor are acknowledged for their suggestions aimed to improve the quality of the manuscript. We thank Davide Comboni for his help with the single-crystal X-ray data collections, Andrea Risplendente for his assistance during the X-ray maps and WDS-EMPA analysis, and Manuel Roda for reading the first draft of the text. Funding by PSR2018_DZANONI, and FFABR2018DZANONI, Univ. Milano. The authors acknowledge the support of the Italian Ministry of Education (MIUR) through the project “Dipartimenti di Eccellenza 2018-2022, Le Geoscienze per la Società: Risorse e loro evoluzione”.

\section{References}

Armbruster, T., Bonazzi, P., Akasaka, M., Bermanec, V., Chopin, C., Gieré, R., Heussassbichler, S., Liebscher, A., Menchetti, S., et al. (2006) Recommended nomenclature of epidotegroup minerals. European Journal of Mineralogy, 18(5), 551-567. doi: 10.1127/09351221/2006/0018-0551

Armstrong, J.T. and Buseck, P.R. (1975) Quantitative chemical analysis of individual microparticles using the electron microprobe. Theoretical. Analytical chemistry, 47(13), 2178-2192. doi: 10.1021/ac60363a033 
Bea, F. (1996) Residence of REE, Y, Th and U in granites and crustal protoliths; implications for the chemistry of crustal melts. Journal of Petrology, 37(3), 521-552. doi: 10.1093/petrology/37.3.521

Berger, A., Rosenberg, C. and Schaltegger, U. (2009) Stability and isotopic dating of monazite and allanite in partially molten rocks: examples from the Central Alps. Swiss Journal of Geosciences, 102(1), 15-29. doi: 10.1007/s00015-009-1310-8

Bonazzi, P., Holtstam, D., Bindi, L., Nysten, P. and Capitani, G. (2009) Multi-analytical approach to solve the puzzle of an allanite-subgroup mineral from Kesebol, Västra Götaland, Sweden. American Mineralogist, 94, 121-134. doi: 10.2138/am.2009.2998

Boston, K.R., Rubatto, D., Hermann, J., Engi, M. and Amelin, Y. (2017) Geochronology of accessory allanite and monazite in the Barrovian metamorphic sequence of the Central Alps, Switzerland. Lithos. doi: 10.1016/j.lithos.2017.06.025

Brooks, C.K., Henderson, P. and Rønsbo, J.G. (1981) Rare-earth partition between allanite and glass in the obsidian of Sandy Braes, Northern Ireland. Mineralogical Magazine, 44, 157-160. doi: 10.1180/minmag.1981.044.334.07

Broska, I. and Siman, P. (1998) The breakdown of monazite in the West-Carpathian Veporic Orthogneisses and Tatric granites. Geologica Carpathica, 49, 161-167.

Broska, I., Petrík, I. and Williams, C.T. (2000) Coexisting monazite and allanite in peraluminous granitoids of the Tribec Mountains, Western Carpathians. American Mineralogist, 85(1), 22-32. doi: 10.2138/am-2000-0104

Carswell, D.A., Wilson, R.N. and Zhai, M. (2000) Metamorphic evolution, mineral chemistry and thermobarometry of schists and orthogneisses hosting ultra-high pressure eclogites in the Dabieshan of central China. Lithos 52, 121-155. doi: 10.1016/S0024-4937(99)00088-2 
Casillas, R., Nagy, G., Pantó, G., Brandle, J. and Fórizs, I. (1995) Occurrence of Th, U, Y, $\mathrm{Zr}$ and REE-bearing accessory minerals in late-Variscan granitic rocks from the Sierra Guadarrama (Spain). European Journal of Mineralogy, 7, 989-1006.

Catlos, E.J., Sorensen, S.S. and Harrison, T.M. (2000) Th-Pb ion-microprobe dating of allanite. American Mineralogist, 85, 633-648, doi: 10.2138/am-2000-5-601

Cenki-Tok, B., Oliot, E., Rubatto, D., Berger, A., Engi, M., Janots, E., Thomsen, T.B., Manzotti, P., Regis, D., Spandler, C., et al. (2011) Preservation of Permian allanite within an Alpine eclogite facies shear zone at Mt Mucrone, Italy: Mechanical and chemical behavior of allanite during mylonitization. Lithos, 125, 40-50. doi: 10.1016/j.lithos.2011.01.005

Cenki-Tok, B., Darling, J.R., Rolland, Y., Dhuime, B. and Storey, C.D. (2014) Direct dating of mid-crustal shear zones with synkinematic allanite: new in situ U-Th-Pb geochronological approaches applied to the Mont Blanc massif. Terra Nova, 26, 29-37. doi: 10.1111/ter.12066

Cliff, R.A., Oberli, F., Meier, M., Droop, G.T R. and Kelly, M. (2015) Syn-metamorphic folding in the Tauern Window, Austria dated by $\mathrm{Th}-\mathrm{Pb}$ ages from individual allanite porphyroblasts. Journal of metamorphic Geology, 33(4), 427-435. doi: 10.1111/jmg.12127

Compagnoni, R., Dal Piaz, G.V., Hunziker, J.C., Gosso G., Lombardo B. and Williams P.F. (1977) The Sesia Lanzo zone, a slice of continental crust with alpine high pressure-low temperature assemblages in the Western Italian Alps. Rendiconti Società Italiana di Mineralogia e Petrografia, $33,281-334$.

Corti, L., Alberelli, G., Zanoni, D. and Zucali, M. (2017) Analysis of fabric evolution and metamorphic reaction progress at Lago della Vecchia-Valle d'Irogna, Sesia-Lanzo Zone, Western Alps. Journal of Maps, 13, 521-533. doi: 10.1080/17445647.2017.1331177 
Corti, L., Alberelli, G., Zanoni, D. and Zucali, M. (2018) Tectonometamorphic evolution of the Lago della Vecchia metaintrusive and its country rocks, Sesia-Lanzo Zone, Western Alps. Italian Journal of Geosciences, 137, 188-207. doi: 10.3301/IJG.2018.08

Corti, L., Zucali, M., Visalli, R., Mancini, L., and Sayab, M. (2019) Integrating X-Ray Computed Tomography with chemical imaging to quantify mineral re-crystallization from granulite to eclogite metamorphism in the Western Italian Alps (Sesia-Lanzo Zone). Frontiers in Earth Science, 7:327. doi: 10.3389/feart.2019.00327

Cox, R.A., Wilton, D.H.C. and Kosler, J. (2003) Laser-ablation U-Th-Pb in situ dating of Zircon and Allanite: an example from the October Harbour Granite, Central Coastal Labrador, Canada. Canadian Mineralogist, 41, 273-291.

Deer, W., Howie, R. and Zussman, J. (1992) An introduction to the rock-forming minerals. Essex: Longman Scientific and Technology.

Delleani, F., Spalla, M.I., Castelli, D. and Gosso, G. (2012) Multiscale structural analysis in the subducted continental crust of the internal Sesia-Lanzo Zone (Monte Mucrone, Western Alps). Journal of Virtual Explorer, 41, 7. doi: 10.3809/jvirtex.2011.00287

Dini, A., Rocchi, S. and Westerman, D.S. (2004) Reaction microtextures of REE-Y-Th-U accessory minerals in the Monte Capanne pluton (Elba Island, Italy): A possible indicator of hybridization processes. Lithos, 78, 101-118. doi: 10.1016/j.lithos.2004.04.045.

Dollase, W.A. (1971) Refinement of the crystal structures of epidote, allanite and hancockite. American Mineralogist, 56, 447-464.

Engi, M. (2017) Petrochronology Based on REE-Minerals: Monazite, Allanite, Xenotime, Apatite: Review in Mineralogy and Geochemistry, 83, 365-418. doi: 10.2138/rmg.2017.83.12 
Exley, R.A. (1980) Microprobe studies of REE-rich accessory minerals: implications for Skye granite petrogenesis and REE mobility in hydrothermal systems. Earth and Planetary Science Letters, 48(1), 97-110.

Finger, F., Broska, I., Roberts, M.P. and Schermaier, A. (1998) Replacement of primary monazite by apatite-allanite-epidote coronas in an amphibolite facies granite gneiss from the eastern Alps. American Mineralogist, 83, 248-258. doi:10.2138/am-1998-3-408.

Fischer, R.X. and Tillmanns, E. (1988) The equivalent isotropic displacement factor. Acta of Crystallography, C44, 775-776.

Franz, G. and Liebscher, A. (2004) Physical and Chemical Properties of the Epidote Minerals. An Introduction. Reviews in mineralogy and geochemistry, 56(1), 1-81. doi: 10.2138/gsrmg.56.1.1

Franz, G., Thomas, S. and Smith, D.C. (1986) High-pressure phengite decomposition in the Weissenstein eclogite, Münchberger Gneiss Massif, Germany. Contributions to Mineralogy and Petrology, 92(1), 71-85.

Gatta, G.D., Nestola, F., and Walter, J.M. (2006) On the thermo-elastic behaviour of kyanite: a neutron powder diffraction study up to 1200 C. Mineralogical Magazine, 70, 309-317. doi: $10.1180 / 0026461067030334$

Gatta, G.D., Rotiroti, N. and Zucali, M. (2009) Plastic deformations in kyanites by tectonometamorphic processes: a single-crystal X-ray diffraction study. Mineralogical Magazine, 73, 359-371. doi: 10.1180/minmag.2009.073.3.359

Gatta, G.D., Meven, M. and Bromiley, G. (2010) Effects of temperature on the crystal structure of epidote: a neutron single-crystal diffraction study at 293 and 1,070 K. Physics and Chemistry of Minerals, 37, 475-485. doi: 10.1007/s00269-009-0348-5 
Gatta, G.D., Alvaro, M. and Bromiley, G. (2011a) A low temperature X-ray single-crystal diffraction and polarised infra-red study of epidote. Physics and Chemistry of Minerals, 39, 1-15. doi: 10.1007/s00269-011-0455-y

Gatta, G.D., Merlini, M., Lee, Y. and Poli, S. (2011b) Behavior of epidote at high pressure and high temperature: a powder diffraction study up to $10 \mathrm{GPa}$ and 1,200 K. Physics and Chemistry of Minerals, 38, 419-428. doi: 10.1007/s00269-010-0415-y

Gatta, G.D., Milani, S., Corti, L., Comboni, D., Lotti, P., Merlini, M. and Liermann, H.P. (2019) Allanite at high pressure: effect of REE on the elastic behaviour of epidote-group minerals. Physics and Chemistry of Minerals, 46, 783-793. doi: 10.1007/s00269-019-01039-9

Gieré, R. and Sorensen, S. (2004) Allanite and Other REE-Rich Epidote-Group Minerals. Review in Mineralogy and Geochemistry, 56, 431-493. doi: 10.2138/gsrmg.56.1.431.

Giuntoli, F. and Engi, M. (2016) Internal geometry of the central Sesia Zone (Aosta Valley, Italy): HP tectonic assembly of continental slices. Swiss Journal of Geosciences, 109(3), 445-471. doi: $10.1007 / \mathrm{s} 00015-016-0225-4$

Goncalves, P., Oliot, E., Marquer, D. and Connolly J.A.D. (2012) Role of chemical processes on shear zone formation: an example from the Grimsel metagranodiorite (Aar massif, Central Alps). Journal of Metamorphic Geology, 30, 703-722. doi:10.1111/j.15251314.2012.00991.x

Gosso, G., Messiga, B., Rebay, G. and Spalla, M.I. (2010) The interplay between deformation and metamorphism during eclogitization of amphibolites in the Sesia-Lanzo zone of the Western Alps. International Geology Review, 51(12), 1193-1219. doi:

$10.1080 / 00206810903529646$ 
Gosso, G., Rebay, G., Roda, M., Spalla, M.I., Tarallo, M.E., Zanoni, D. and Zucali, M. (2015) Taking advantage of petrostructural heterogeneities in subduction-collisional orogens, and effect on the scale of analysis. Periodico di Mineralogia, 84(3B), 779-825. doi: $10.2451 / 2015 \mathrm{PM} 0452$

Gregory, C.J., Rubatto, D., Allen, M.A., Williams, I.S., Hermann, J. and Ireland, T. (2007) Allanite micro-geochronology: A LA-ICP-MS and SHRIMP U-Th-Pb study. Chemical Geology, 245, 162-182. doi: 10.1016/j.chemgeo.2007.07.029

Gregory, C.J., Rubatto, D., Hermann, J., Berger, A. and Engi, M. (2012) Allanite behaviour during incipient melting in the southern Central Alps. Geochimica et Cosmochimica Acta, 84, 433458. doi: 10.1016/j.gca.2012.01.020

Gromet, L.P. and Silver, L.T. (1983) Rare earth element distributions among minerals in a granodiorite and their petrogenetic implications. Geochimica et Cosmochimica Acta, 47(5), 925939. doi: 10.1016/0016-7037(83)90158-8

Hermann, J. (2002) Allanite: thorium and light rare earth element carrier in subducted crust. Chemical Geology, 192, 289-306. doi: 10.1016/S0009-2541(02)00222-X

Hermann, J. and Rubatto, D. (2009) Accessory phase control on the trace element signature of sediment melts in subduction zones. Chemical Geology, 265, 512-526. doi: 10.1016/j.chemgeo.2009.05.018

Janots, E., Brunet, F., Goffé, B., Poinssot, C., Burchard, M. and Cemič, L. (2007) Thermochemistry of monazite-(La) and dissakisite-(La): implications for monazite and allanite stability in metapelites: Contribution in Mineralogy and Petrology, 154, 1-14, doi: 10.1007/s00410006-0176-2 
Janots, E., Engi, M., Berger, A., Allaz, J., Schwarz, J.O. and Spandler, C. (2008) Prograde metamorphic sequence of REE minerals in pelitic rocks of the Central Alps: implications for allanite-monazite-xenotime phase relations from 250 to $610^{\circ} \mathrm{C}$. Journal of Metamorphic Geology, 26, 509-526. doi: 10.1111/j.1525-1314.2008.00774.x

Jarosewich, E. and Boatner, L.A. (1991) Rare-Earth Element Reference Samples for Electron Microprobe Analysis. Geostandards Newsletter, 15, 397-399. doi: 10.1111/j.1751908X.1991.tb00115.x

Kim, Y., Cheong, C.S., Lee, Y. and Williams, I.S. (2009) SHRIMP allanite U-Th-Pb dating of bimodal Triassic metamorphism of Neoarchean tonalitic gneisses, Daeijak Island, central Korea. Geosciences Journal, 13(3), 305-315.

Lardeaux, J.M. and Spalla, M.I. (1990) Tectonic significance of P-T-t paths in metamorphic rocks: examples from ancient and modern orogenic belts. Memorie della Società Geologica Italiana, 45, 51-65.

Lee, D.E. and Silver, L.T. (1964) Accessory minerals in some granitic rocks in California and Nevada as a function of calcium content. American Mineralogist, 49, 1660-1670.

Liu, X., Dong, S., Xue, H. and Zhou, J. (1999) Significance of allanite-(Ce) in granitic gneisses from the ultrahigh-pressure metamorphic terrane, Dabie Shan, central China: Mineralogical Magazine, 63, 579-586. doi: 10.1180/minmag.1999.063.4.10

Liu, X., Shieh, S.R., Fleet, M.E. and Zhang, L. (2009) Compressibility of a natural kyanite to 17.5 GPa. Progress in Natural Science, 19, 1281-1286. doi: 10.1016/j.pnsc.2009.04.001

Manzotti, P., Bosse, V., Pitra, P., Robyr, M., Schiavi, F. and Ballèvre, M. (2018) Exhumation rates in the Gran Paradiso Massif (Western Alps) constrained by in situ U-Th- $\mathrm{Pb}$ 
dating of accessory phases (monazite, allanite and xenotime). Contributions to Mineralogy and Petrology, 173(3), 24. doi: 10.1007/s00410-018-1452-7

Middlemost, E.A.K. (1985). Magma and magmatic Rocks: An Introduction to Igneous Petrology. Longman Ed., London, 266 pp.

Moore, J.M. and McStay, J. H. (1990) The formation of allanite-(Ce) in calcic granofelses, Namaqualand, South Africa. The Canadian Mineralogist, 28(1), 77-86.

Ortolano, G., Zappalà, L. and Mazzoleni, P. (2014a) X-Ray Map Analyser: A new ArcGIS® based tool for the quantitative statistical data handling of X-ray maps (Geo-and material-science applications). Computer and Geosciences, 72, 49-58. doi: 10.1016/j.cageo.2014.07.006

Ortolano, G., Visalli, R., Cirrincione, R. and Rebay, G. (2014b) PT-path reconstruction via unraveling of peculiar zoning pattern in atoll shaped garnets via image assisted analysis: an example from the Santa Lucia del Mela garnet micaschists (northeastern Sicily-Italy). Periodico di Mineralogia, 83, 257-297. doi: 10.2451/2013PM0015

Ortolano, G., Visalli, R., Godard, G. and Cirrincione, R. (2018) Quantitative X-ray Map Analyser (Q-XRMA): A new GIS-based statistical approach to Mineral Image Analysis. Computers and Geosciences, 115, 56-65. doi: 10.1016/j.cageo.2018.03.001

Punturo, R., Cirrincione, R., Fazio, E., Fiannacca, P., Kern, H., Mengel, K., Ortolano, G. and Pezzino, A. (2014) Microstructural, compositional and petrophysical properties of mylonitic granodiorites from an extensional shear zone (Rhodope Core complex, Greece). Geological Magazine, 151, 1051-1071. doi: 10.1017/S001675681300109X

Qin, F.W., Wang, Y., Fan, D., Qin, S., Yang, K., Townsend, J.P. and Jacobsen, S.D. (2016) High-pressure behavior of natural single-crystal epidote and clinozoisite up to $40 \mathrm{GPa}$. Physics and Chemistry of Minerals, 43, 649-659. doi: 10.1007/s00269-016-0824-7 
Radulescu, I.G., Rubatto, D., Gregory, C. and Compagnoni, R. (2009) The age of HP metamorphism in the Gran Paradiso Massif, Western Alps: a petrological and geochronological study of "silvery micaschists". Lithos, 110(1-4), 95-108. doi: 10.1016/j.lithos.2008.12.008

Ramberg, H. (1955) Natural and experimental boudinage and pinch-and-swell structures. The Journal of Geology, 63, 512-526. doi: 10.1086/626293

Rasmussen, B., Muhling, J.R., Fletcher, I.R. and Wingate, M.T.D. (2006) In situ SHRIMP $\mathrm{U}-\mathrm{Pb}$ dating of monazite integrated with petrology and textures: Does bulk composition control whether monazite forms in low-Ca pelitic rocks during amphibolite facies metamorphism? Geochimica et Cosmochimica Acta, 70, 3040-3058. doi: 10.1016/j.gca.2006.03.025

Regis, D., Rubatto, D., Darling, J., Cenki-Tok, B., Zucali, M. and Engi, M. (2014) Multiple metamorphic stages within an eclogite-facies terrane (Sesia Zone, Western Alps) revealed by ThU-Pb petrochronology. Journal of Petrology, 55, 1429-1456. doi: 10.1093/petrology/egu029

Roda, M., Spalla, M.I. and Marotta, A.M. (2012) Integration of natural data within a numerical model of ablative subduction: a possible interpretation for the Alpine dynamics of the Austroalpine crust. Journal of Metamorphic Geology, 30 (9), 973-996. doi:10.1111/jmg.12000

Roda, M., De Salvo, F., Zucali, M. and Spalla, M.I. (2018) Structural and metamorphic evolution during tectonic mixing: is the Rocca Canavese Thrust Sheet (Italian Western Alps) a subduction-related mélange? Italian Journal of Geosciences, 137 (2), 311-329. doi: 10.3301/IJG.2018.17

Roda, M., Zucali, M., Regorda, A. and Spalla, M.I. (2019) Formation and evolution of a subduction-related mélange: The example of the Rocca Canavese Thrust Sheets (Western Alps). GSA Bulletin. doi: 10.1130/B35213.1 
Schmidt, M.W. and Thompson, A.B. (1996) Epidote in calcalkaline magmas; an experimental study of stability, phase relationships, and the role of epidote in magmatic evolution. American Mineralogist, 81(3-4), 462-474. doi: 10.2138/am-1996-3-420

Sheldrick, G.M. (1997) SHELXL-97. Programs for crystal structure determination and refinement. University of Göttingen, Germany.

Smith, H.A. and Barreiro, B. (1990) Monazite U-Pb dating of staurolite grade metamorphism in pelitic schists. Contributions to Mineralogy and Petrology, 105(5), 602-615. doi: 10.1007/BF00302498

Sorensen, S.S. (1991) Petrogenetic significance of zoned allanite in garnet amphibolites from a paleo-subduction zone: Catalina Schist, southern California. American Mineralogist, 76(34), 589-601.

Spalla, M.I., Lardeaux, J.M., Dal Piaz, G.V. and Gosso, G. (1991) Métamorphisme et tectonique à la marge externe de la zone Sesia-Lanzo (Alpes occidentales): Memorie di Scienze Geologiche, 43, 361-369.

Spear, F.S. (2010) Monazite-allanite phase relations in metapelites. Chemical Geology, 279, 55-62. doi: 10.1016/j.chemgeo.2010.10.004

Tomkins, H.S. and Pattison, D.R.M. (2007) Accessory phase petrogenesis in relation to major phase assemblages in pelites from the Nelson contact aureole, southern British Columbia. Journal of Metamorphic Geology, 25(4), 401-421. doi: 10.1111/j.1525-1314.2007.00702.x

Tribuzio, R., Messiga, B., Vannucci, R. and Bottazzi, P. (1996) Rare earth element redistribution during high-pressure-low-temperature metamorphism in ophiolitic Fe-gabbros (Liguria, northwestern Italy): implications for light REE mobility in subduction zones. Geology, 24(8), 711-714. doi: 10.1130/0091-7613(1996)024<0711:REERDH>2.3.CO;2 
Whitney, D.L. and Evans, B.W. (2010) Abbreviations for names of rock-forming minerals: American Mineralogist, 95, 185-187. doi: 10.2138/am.2010.3371

Wing, B.A., Ferry, J.M. and Harrison, T.M. (2003) Prograde destruction and formation of monazite and allanite during contact and regional metamorphism of pelites: petrology and geochronology. Contribution in Mineralogy and Petrology, 145, 228-250. doi: 10.1007/s00410003-0446-1

Zucali, M. (2011) Coronitic microstructures in patchy eclogitised continental crust: the Lago della Vecchia pre-Alpine metagranite (Sesia-Lanzo Zone, Western Italian Alps). Journal of Virtual Explorer, 38, 3-28. doi: 10.3809/jvirtex.2011.00286.

Zucali, M. and Spalla, M.I. (2011) Prograde lawsonite during the flow of continental crust in the Alpine subduction: Strain vs. metamorphism partitioning, a field-analysis approach to infer tectonometamorphic evolutions (Sesia-Lanzo Zone, Western Italian Alps). Journal of Structural Geology, 33, 381-398. doi: 10.1016/j.jsg.2010.12.006

Zucali, M., Spalla, M.I. and Gosso, G. (2002) Strain partitioning and fabric evolution as a correlation tool: the example of the Eclogitic Micaschists Complex in the Sesia-Lanzo Zone (Monte Mucrone-Monte Mars, Western Alps, Italy). Schweizerische Mineralogische und Petrographische Mitteilungen, 82, 429-454.

Zucali, M., Corti, L., Delleani, F., Zanoni, D. and Spalla, M.I. (2020). 3D reconstruction of fabric and metamorphic domains in a slice of continental crust involved in the alpine subduction system: the example of Mt. Mucrone (Sesia-Lanzo Zone, Western Alps). International Journal of Earth Science. doi: 10.1007/s00531-019-01807-6 


\section{Captions}
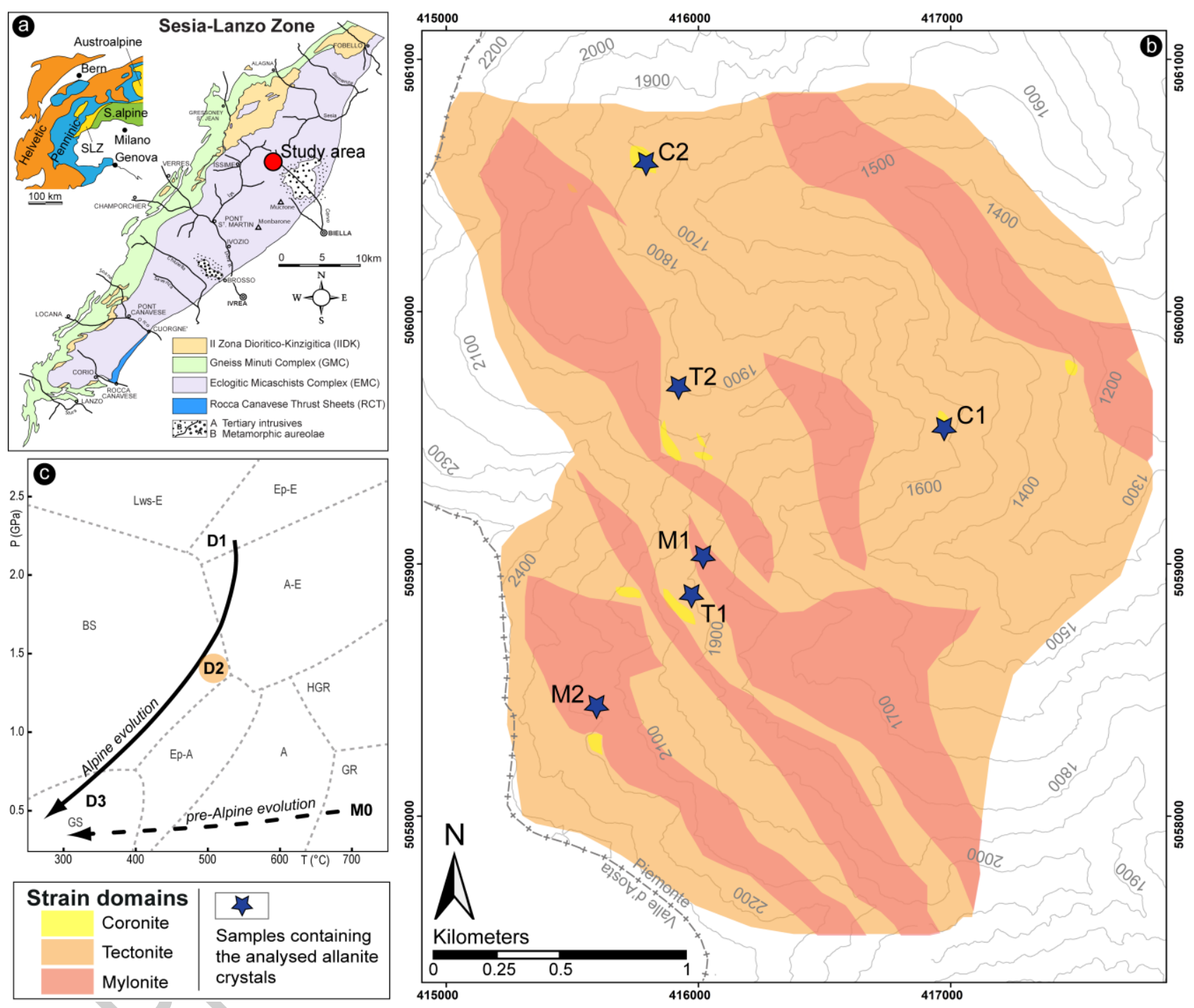

Figure 1. a) Location of the study area in the Sesia-Lanzo Zone, Western Alps. b) D2 fabric domains and location of analysed allanite-(Ce) crystals (UTM 32N-WGS84; modified after Corti et al., 2017). c) P-T-d-t path and D2 dominant fabric conditions as inferred by Corti et al. (2018). 

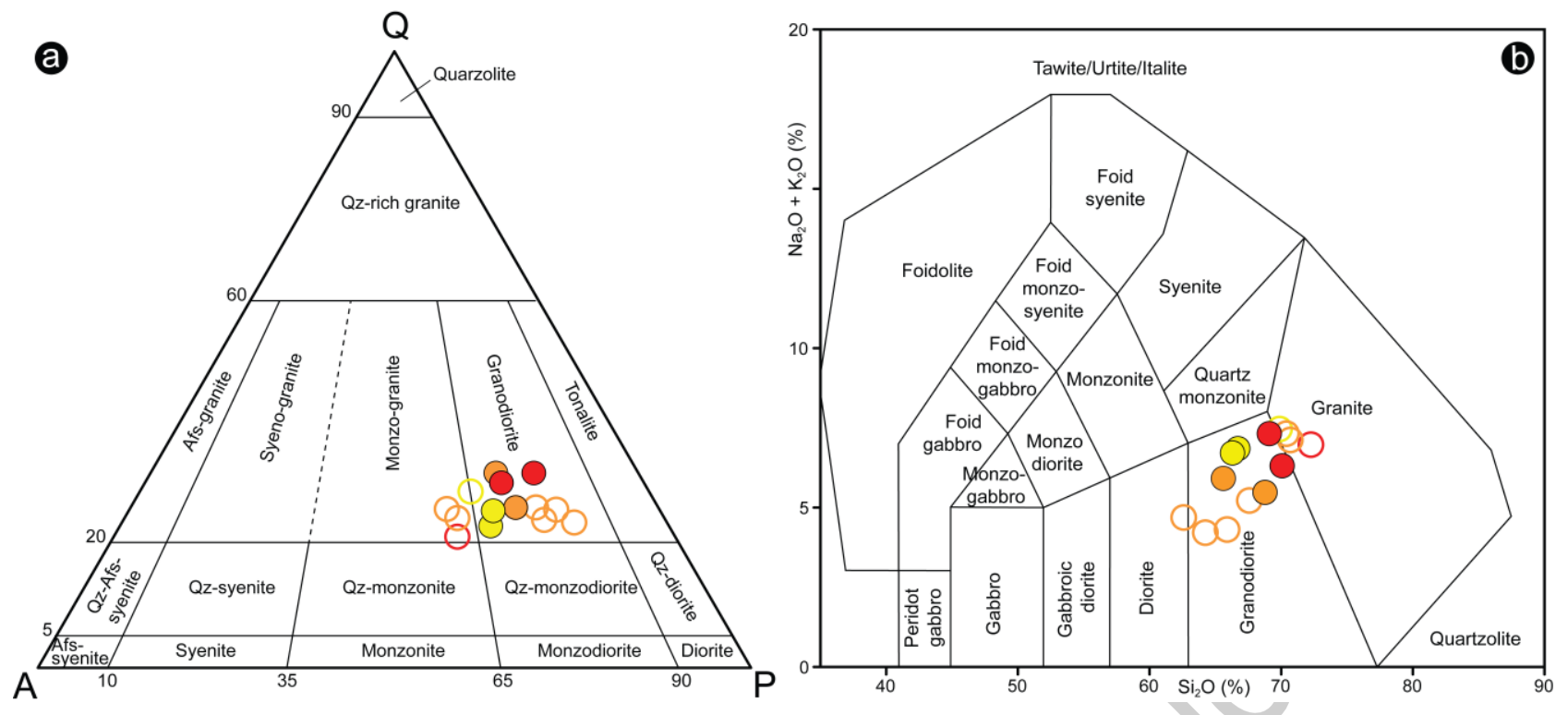

Figure 2. Estimated bulk-rock composition based on the integration of modal mineral content, mineral chemistry, and CIPW normative analysis. Allanite-(Ce) crystals of this study are from coronitic samples (yellow); tectonitic samples (orange); mylonitic samples (red). The light-blue symbols are from Corti et al., (2018). a) QAP diagram used to classify granitoid rocks - Q: quartz; A: alkali feldspar; P: plagioclase (normalized to 100\%). b) Metagranitoid samples plotted on TAS diagram (modified after Middlemost, 1985). 

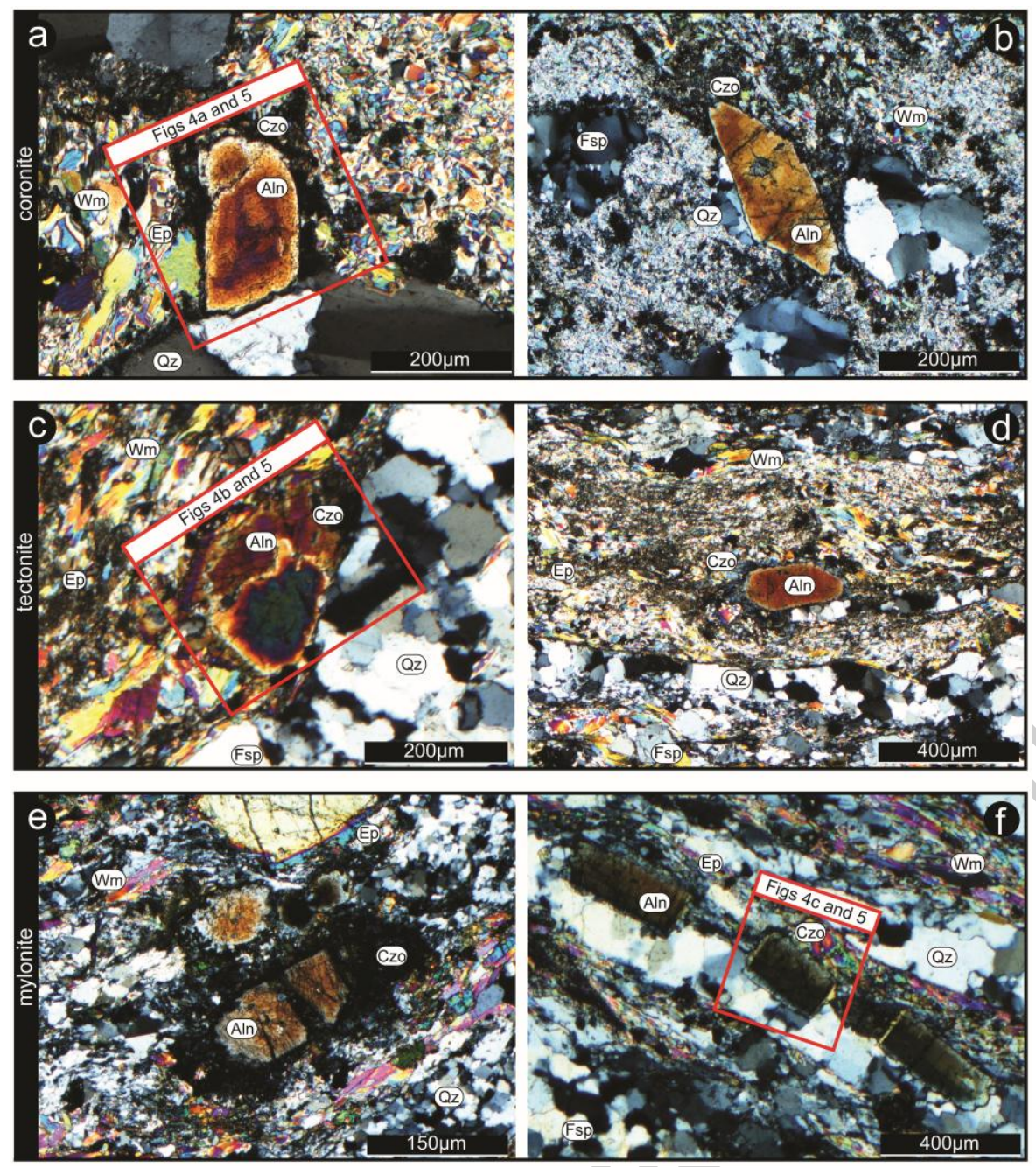

Figure 3. Microstructural features of the analysed Aln crystals (crossed polars). In coronitic domains (a: sample C1, UTM: 417087 - 5059526; b: sample C2, UTM: 415879 - 5060637), Aln occurs in well-preserved single crystals rimmed by Czo and surrounded by fine-grained rock-matrix constituted by Wm + Ep + Qz. In tectonitic domains (c: sample T1, UTM: 415994 - 5058867; d: sample T2, UTM: 4159071 - 5059737), Aln porphyroclast is partially replaced by Czo and it is wrapped by $\mathrm{Wm}+\mathrm{Ep}+\mathrm{Qz}+$ Fsp assemblage marking the S2 foliation. In mylonitic domains (e: sample M1, UTM: 416137 - 5059099; f: sample M2, UTM: 415699 - 5058603), Aln crystals are aligned and boudinated along $\mathrm{S} 2$ that is constituted by $\mathrm{Qz}+\mathrm{Wm}+\mathrm{Fsp}+\mathrm{Czo}+\mathrm{Ep}$ assemblage. The location of the X-ray maps is shown (red rectangle). 

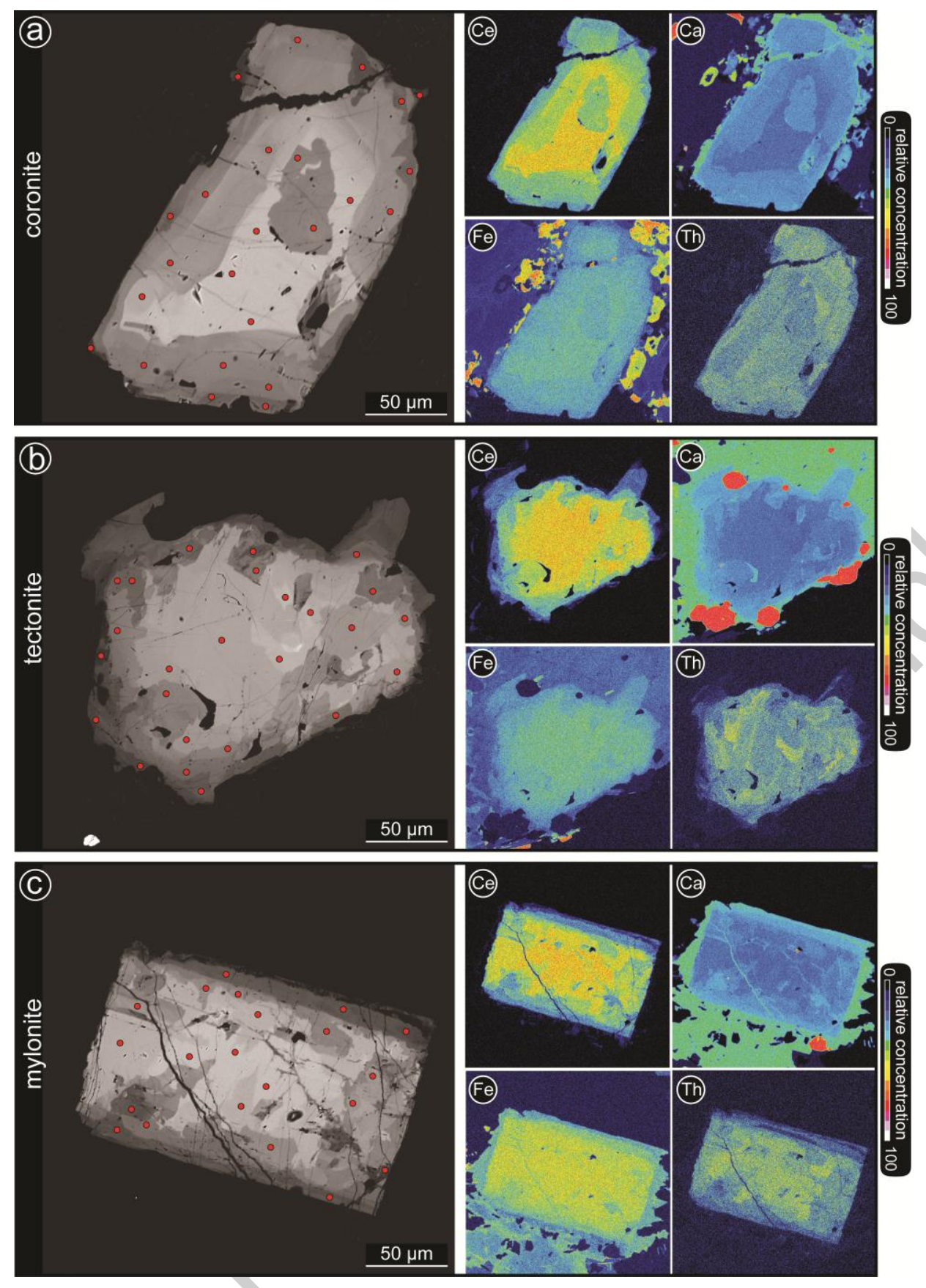

Figure 4. BSE images and X-Ray elemental maps (WDS: Ce and Th; EDS: Ca and Fe) of an Aln crystal in (a) coronitic domain, (b) tectonitic domain, and (c) mylonitic domain. Red circles indicate the position of the mineral chemical analyses in Aln. The chemical pattern shows as the concentric zonation in coronitic domain is mostly given by the decrease of Ce content and the increase of Ca and Fe contents towards the crystal rim. The element partitioning generates patchwork and enechelon-like chemical zonation in tectonite and mylonite domains, respectively. 

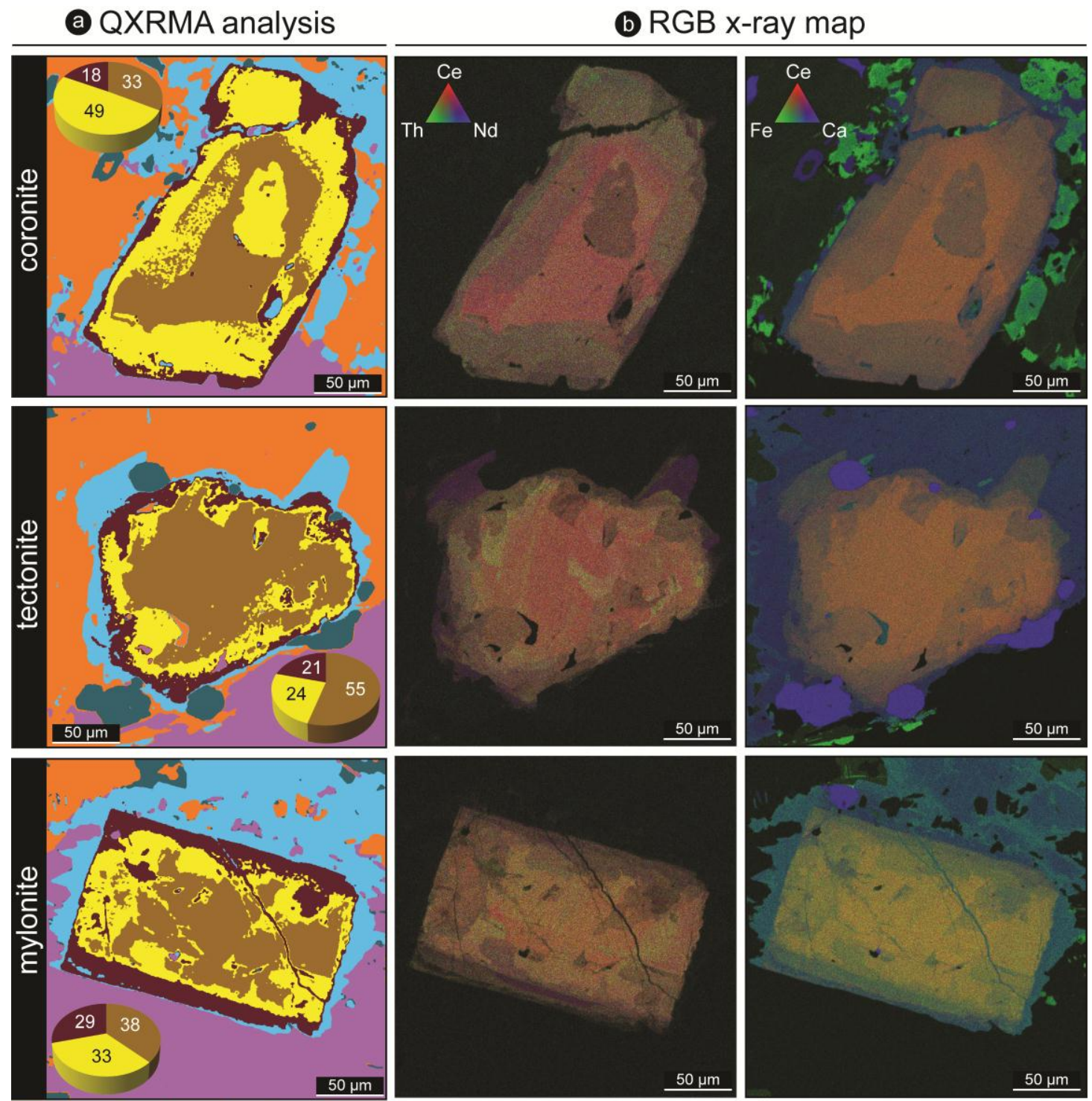

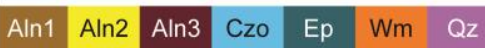

Figure 5. (a) QXRMA results, with type and spatial distribution of the mineral species, along with the modal fraction of Aln chemical zoning in relation with the domains of progressive strain. (b) RGB X-ray maps that show Ce-Th-Nd and Ce-Fe-Ca pattern within Aln crystals in relation with the domains of progressive strain. A clear decrease of Ce content in all strain domains, concentric zonation in the coronitic domains, patchwork zonation in the tectonitic domains, and en-echelonlike zonation in the mylonitic domains, oblique with respect to S2, are evident in Aln porphyroclasts. 


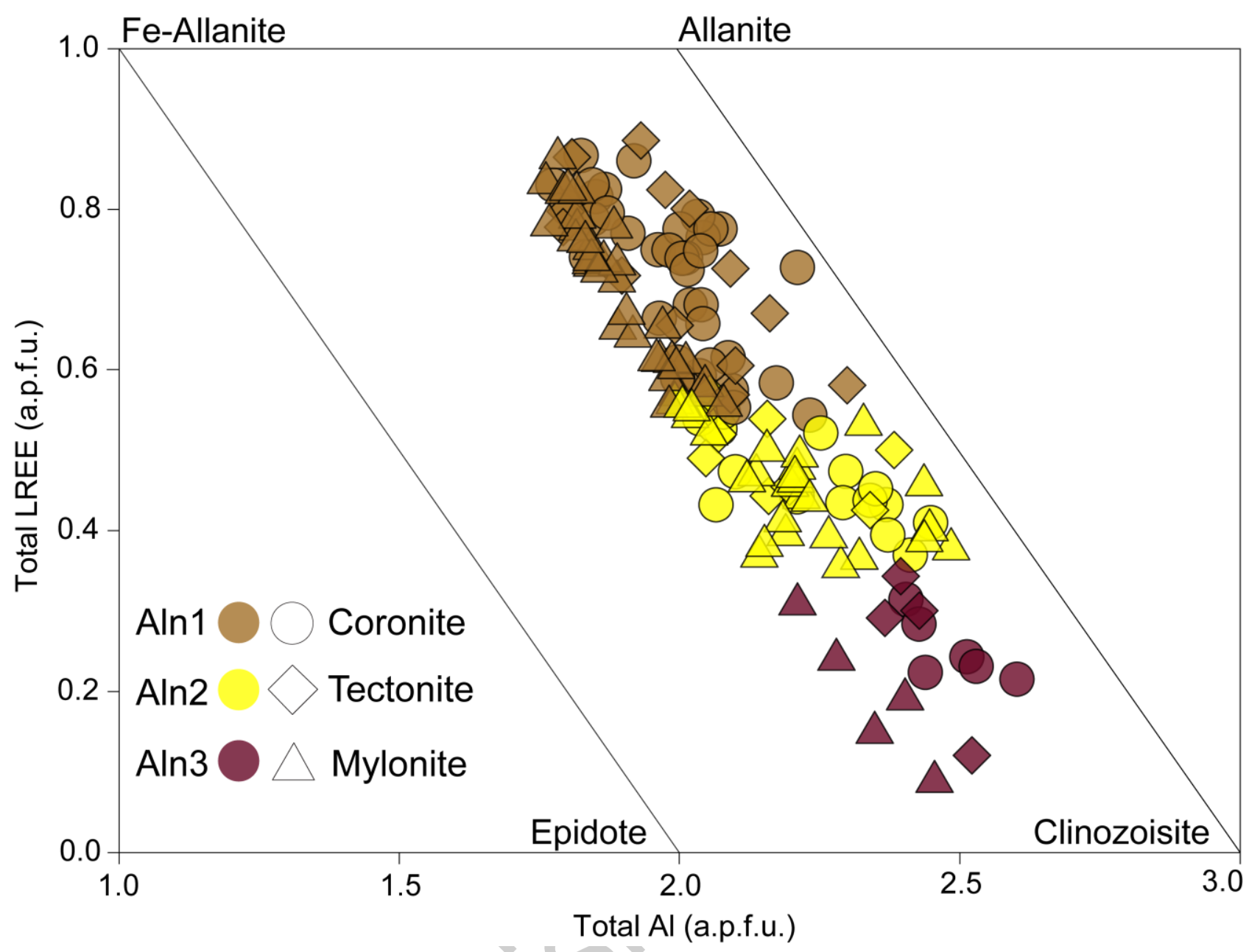

Figure 6. Total LREE vs. Al content diagram shows the chemical variation in allanite-(Ce) crystals from core (Aln1) to rim (Aln3) in the different strain domains (circle: coronite, diamond: tectonite, triangle: mylonite). 


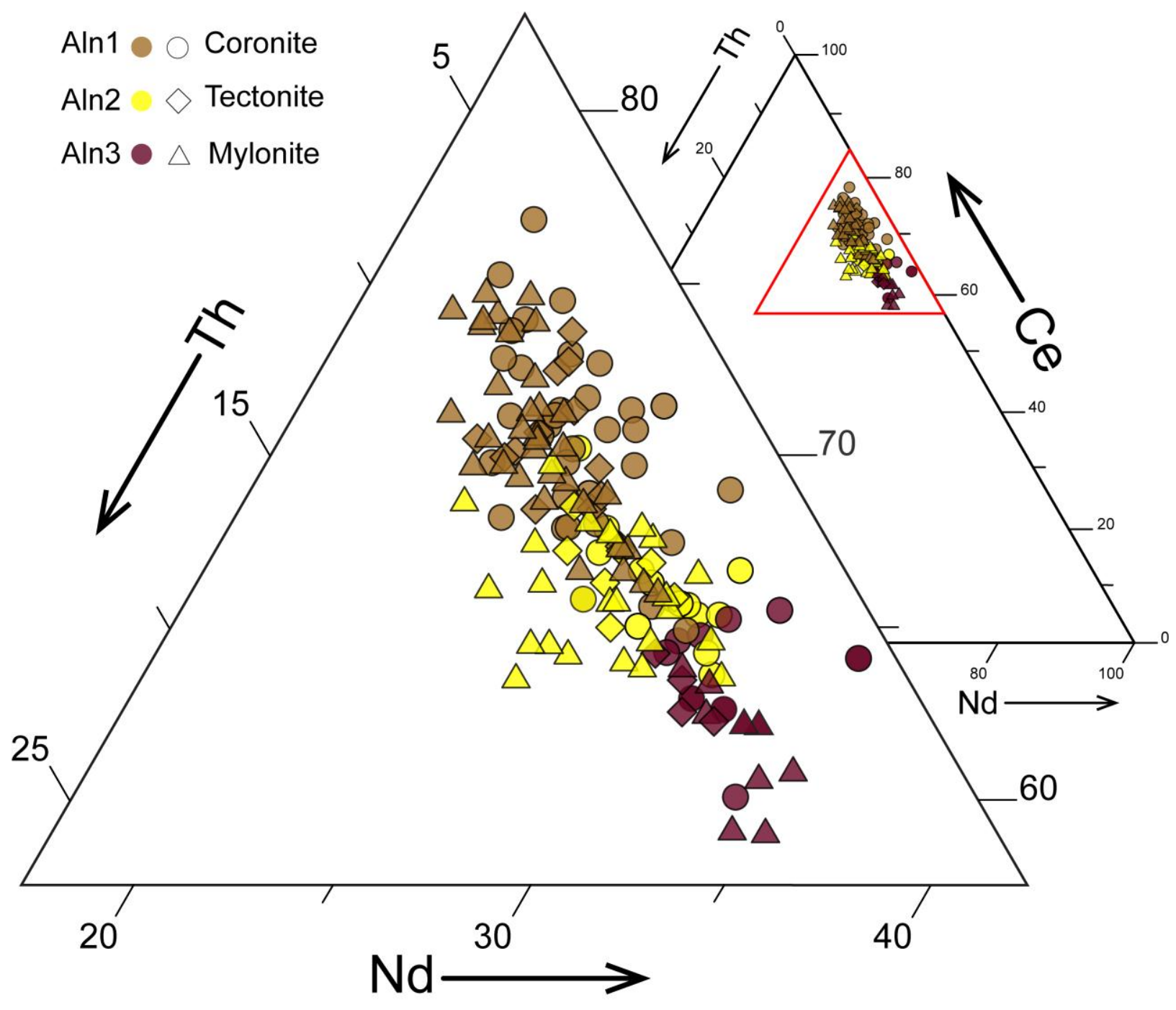

Figure 7. Ce-Th-Nd triangular plot shows the chemical variation in allanite-(Ce) crystals from core (Aln1) to rim $(\mathrm{A} \ln 3)$ in the different strain domains (circle: coronite, diamond: tectonite, triangle: mylonite). 


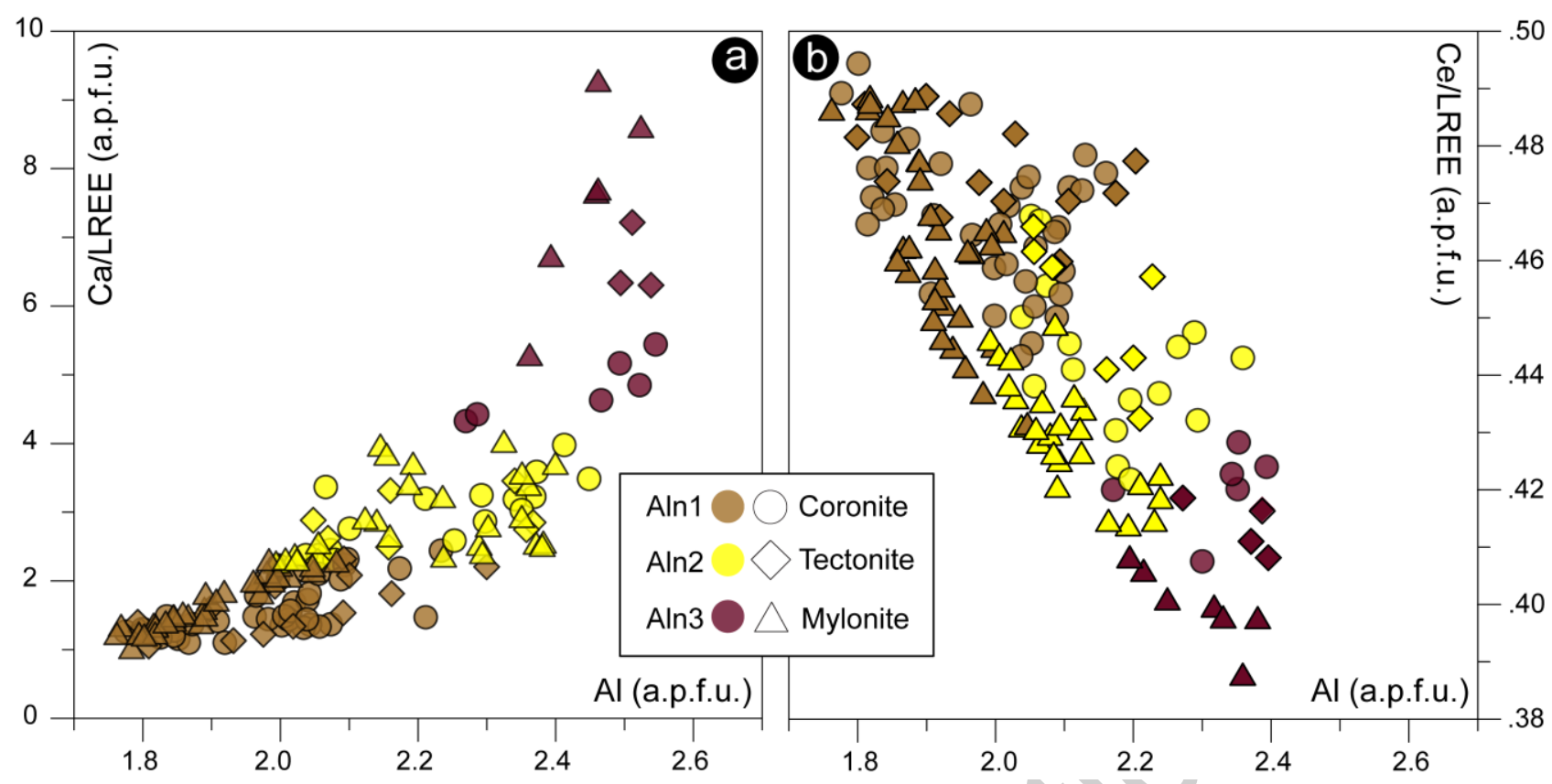

Figure 8. Chemical variation in allanite-(Ce) crystals from core (Aln1) to rim (Aln3) in the different strain domains (circle: coronite, diamond: tectonite, triangle: mylonite). a) Ca/LREE ratio vs. $\mathrm{Al}$ content. b) $\mathrm{Ce} / \mathrm{LREE}$ ratio vs. Al content. 

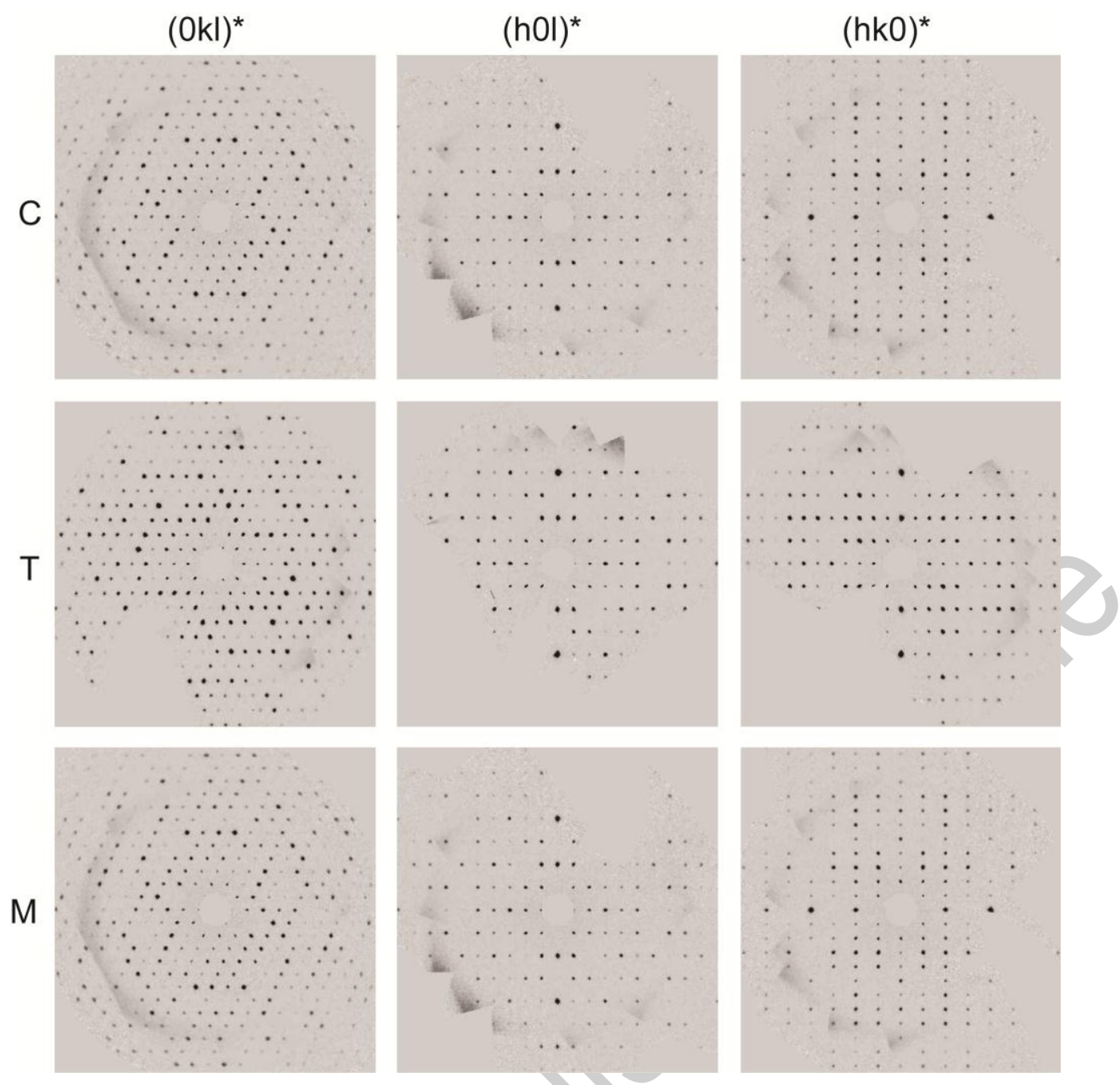

Figure 9. Unwarped single-crystal diffraction patterns (based on raw data) of the allanite-(Ce) crystals from the different strain domains $(\mathrm{C}=$ coronitic, $\# 1.10 ; \mathrm{T}=$ tectonitic, $\# 5.5 ; \mathrm{M}=$ mylonitic, \#8.1, see also the CIFs and Table S1). 


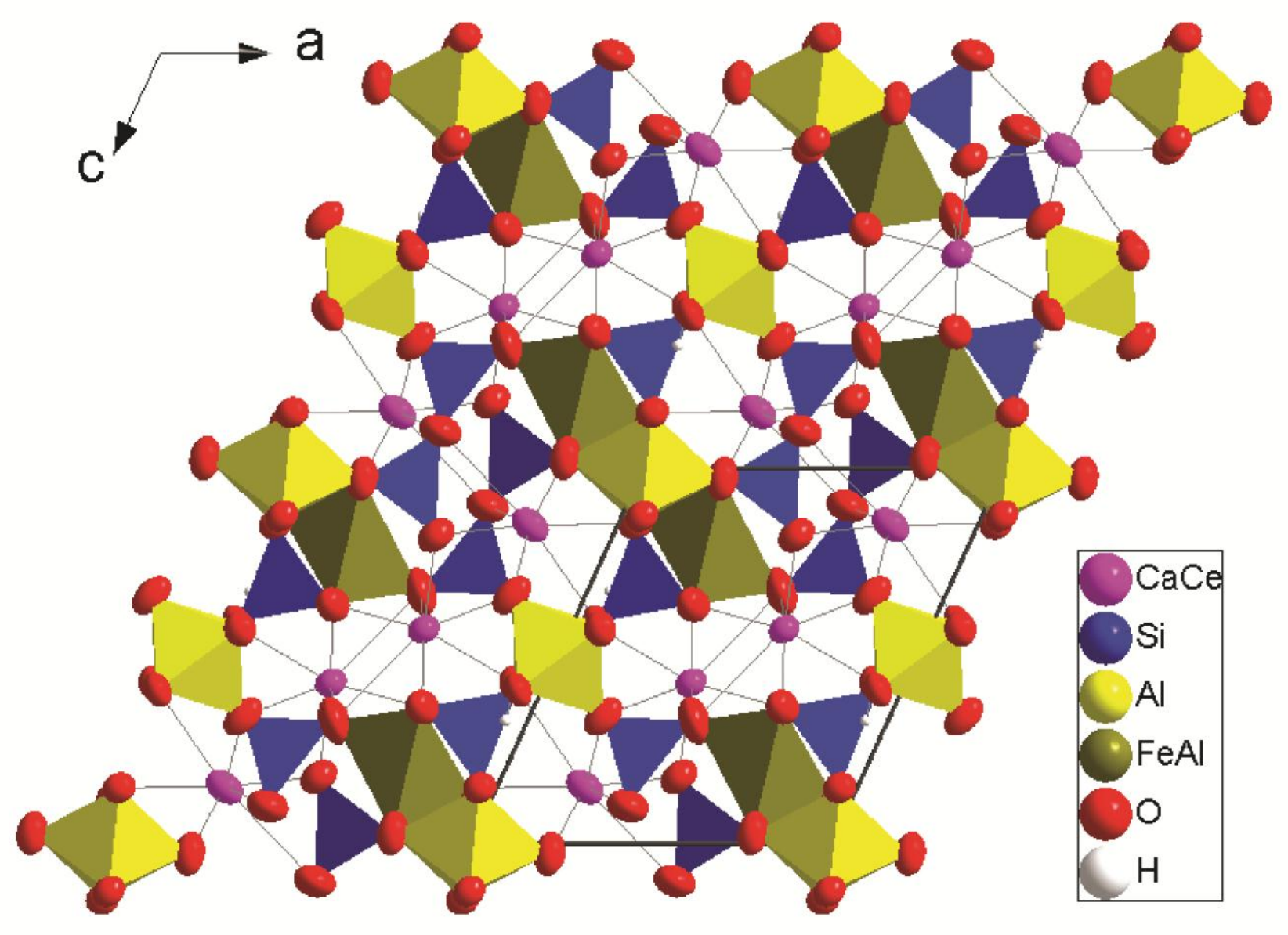

Figure 10. Output of the anisotropic structure refinement of the Aln crystal (\#8.1) from a mylonitic domain (atomic displacement probability factor: 99\%). It is evident the modest anisotropy of the atomic displacement ellipsoids, in line with the previous findings for gem-quality epidote crystals (see text for further details). 

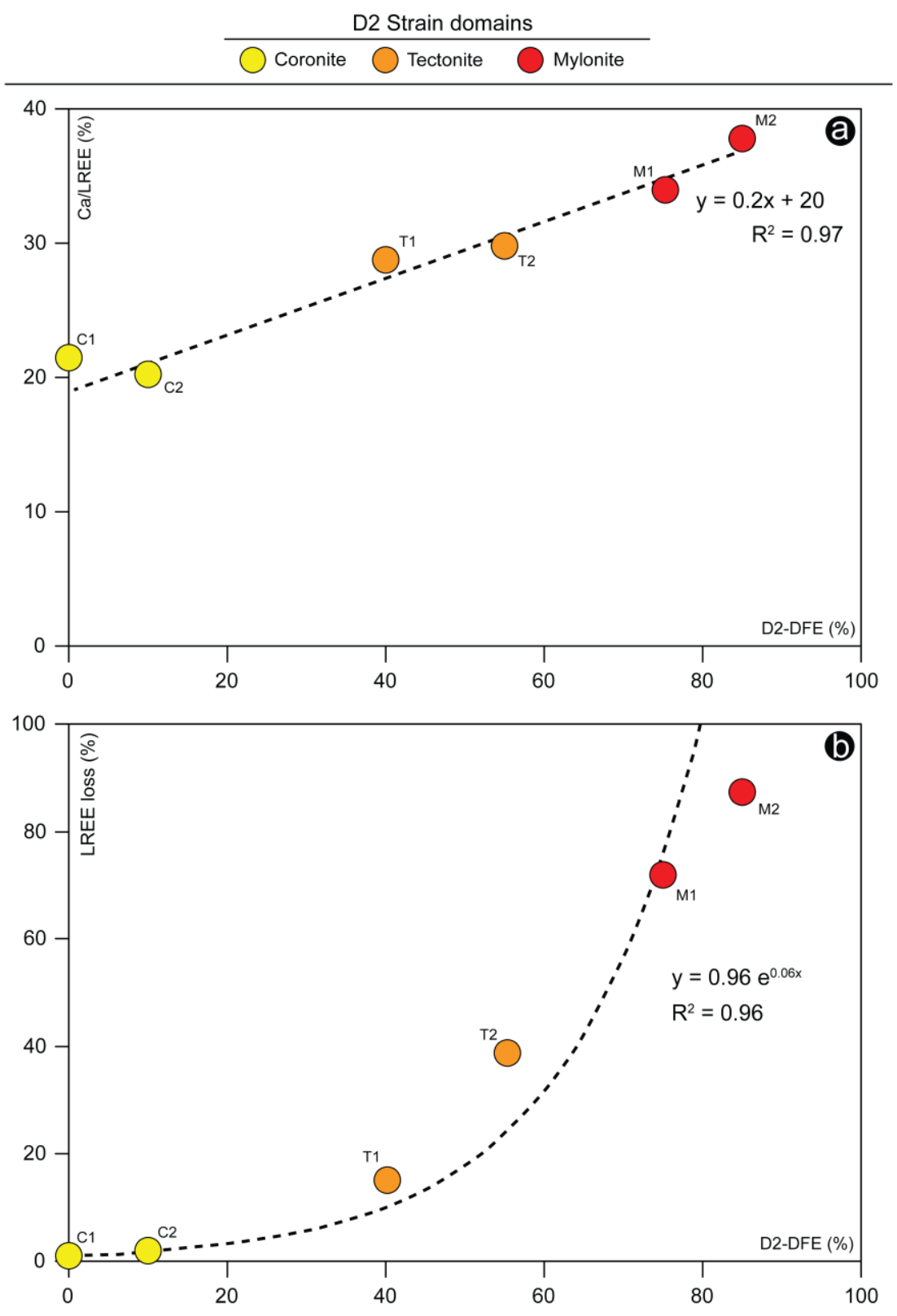

Figure 11. LREE release. a) Normalised Ca/LREE ratio vs. D2-stage Degree of Fabric Evolution estimated for each sample. The label of each sample is reported. The linear regression and the related coefficient of determination between Ca/LREE ratio during the D2 strain accumulation is reported. b) LREE loss vs. D2-stage Degree of Fabric Evolution estimated for each sample. The exponential regression and the related coefficient of determination between LREE released during the D2 strain accumulation is reported. 
Table 1. WDS-EPMA data of 18 selected allanite-(Ce) from the three strain domains (i.e., C: coronite, T: tectonite, and M: mylonite).

\begin{tabular}{|c|c|c|c|c|c|c|c|c|c|c|c|c|c|c|c|c|c|c|}
\hline \multirow{2}{*}{$\begin{array}{l}\text { Sample } \\
\text { Subphas } \\
\text { e }\end{array}$} & \multicolumn{3}{|c|}{$\mathrm{C} 1$} & \multicolumn{3}{|c|}{$\mathrm{C} 2$} & \multicolumn{3}{|c|}{$\mathrm{T} 1$} & \multicolumn{3}{|c|}{$\mathrm{T} 2$} & \multicolumn{3}{|c|}{ M1 } & \multicolumn{3}{|c|}{ M2 } \\
\hline & Aln1 & Aln2 & Aln3 & Aln1 & Aln2 & Aln3 & Aln1 & Aln2 & $\underset{*}{A \ln 3^{* *}}$ & Aln1 & Aln2 & $\begin{array}{c}A \ln 3^{* *} \\
*\end{array}$ & Aln1 & Aln2 & $\underset{*}{\operatorname{Aln} 3^{* *}}$ & Aln1 & Aln2 & $\underset{*}{A \ln 3^{* *}}$ \\
\hline $\mathrm{SiO}_{2}$ & 32.95 & 34.45 & 36.13 & 32.05 & 34.76 & 36.05 & 33.41 & 34.30 & 36.08 & 32.52 & 34.37 & 36.08 & 33.35 & 34.35 & 35.84 & 33.08 & 34.83 & 35.63 \\
\hline $\mathrm{TiO}_{2}$ & 0.22 & 0.53 & 0.20 & 0.77 & 0.46 & 0.18 & 0.61 & 0.58 & 0.12 & 0.68 & 0.34 & 0.12 & 0.51 & 0.21 & 0.13 & 0.64 & 0.20 & 0.30 \\
\hline $\mathrm{Al}_{2} \mathrm{O}_{3}$ & 18.65 & 20.19 & 25.93 & 17.35 & 20.90 & 24.83 & 18.64 & 19.75 & 24.05 & 18.43 & 19.69 & 24.05 & 18.83 & 21.65 & 22.59 & 17.40 & 24.12 & 22.17 \\
\hline $\mathrm{Fe}_{2} \mathrm{O}_{3}$ & 0.24 & 2.81 & 1.49 & 0.01 & 1.76 & 0.01 & 2.18 & 4.79 & 3.22 & 0.02 & 3.55 & 1.96 & 3.12 & 2.71 & 3.77 & 2.27 & 0.36 & 5.56 \\
\hline $\mathrm{FeO}^{*}$ & 12.15 & 9.85 & 7.54 & 12.62 & 9.53 & 7.97 & 10.24 & 8.33 & 6.85 & 11.99 & 9.04 & 6.97 & 9.60 & 8.84 & 7.03 & 11.35 & 8.30 & 6.54 \\
\hline $\mathrm{MgO}$ & 0.67 & 0.57 & 0.23 & 0.74 & 0.40 & 0.24 & 0.49 & 0.35 & 0.21 & 0.62 & 0.51 & 0.21 & 0.59 & 0.37 & 0.26 & 0.73 & 0.39 & 0.37 \\
\hline $\mathrm{CaO}$ & 10.56 & 13.63 & 16.57 & 9.88 & 14.32 & 16.32 & 12.96 & 15.00 & 17.11 & 10.77 & 14.21 & 17.11 & 13.10 & 14.31 & 16.89 & 11.61 & 15.06 & 16.96 \\
\hline $\mathrm{La}_{2} \mathrm{O}_{3}$ & 5.24 & 2.87 & 1.81 & 6.23 & 3.52 & 3.04 & 4.51 & 3.51 & 2.36 & 5.71 & 3.51 & 2.36 & 3.91 & 3.61 & 2.91 & 4.53 & 2.94 & 1.86 \\
\hline $\mathrm{Ce}_{2} \mathrm{O}_{3}$ & 10.95 & 7.39 & 4.25 & 12.50 & 7.82 & 6.58 & 9.57 & 7.51 & 5.37 & 11.14 & 7.83 & 5.37 & 8.64 & 7.75 & 5.06 & 10.20 & 5.98 & 4.12 \\
\hline $\mathrm{Pr}_{2} \mathrm{O}_{3}$ & 2.55 & 1.57 & 0.80 & 2.36 & 1.71 & 1.17 & 1.91 & 1.34 & 1.07 & 2.46 & 1.71 & 1.07 & 1.82 & 1.65 & 1.03 & 2.19 & 1.62 & 0.93 \\
\hline $\mathrm{Nd}_{2} \mathrm{O}_{3}$ & 4.03 & 4.06 & 1.88 & 4.01 & 3.27 & 2.16 & 3.26 & 2.53 & 2.07 & 3.67 & 3.00 & 2.07 & 3.62 & 2.81 & 1.60 & 3.77 & 2.66 & 2.42 \\
\hline $\mathrm{Sm}_{2} \mathrm{O}_{3}$ & 0.73 & 1.01 & 0.57 & 0.59 & 0.60 & 0.33 & 0.58 & 0.40 & 0.30 & 0.64 & 0.79 & 0.30 & 0.64 & 0.43 & 0.43 & 0.65 & 0.54 & 0.83 \\
\hline $\mathrm{ThO}_{2}$ & 0.75 & 0.83 & 0.52 & 0.92 & 1.00 & 0.91 & 1.44 & 0.83 & 0.60 & 0.96 & 0.97 & 0.60 & 1.05 & 0.88 & 0.77 & 1.34 & 1.15 & 0.45 \\
\hline $\mathrm{H}_{2} \mathrm{O}^{* *}$ & 1.62 & 1.70 & 1.80 & 1.59 & 1.71 & 1.78 & 1.65 & 1.70 & 1.79 & 1.61 & 1.69 & 1.77 & 1.65 & 1.71 & 1.76 & 1.63 & 1.74 & 1.76 \\
\hline Total & $\begin{array}{c}101.3 \\
1\end{array}$ & $\begin{array}{c}101.4 \\
7\end{array}$ & 99.72 & $\begin{array}{c}101.6 \\
3\end{array}$ & $\begin{array}{c}101.7 \\
5\end{array}$ & 101.5 & $\begin{array}{c}101.4 \\
5\end{array}$ & $\begin{array}{c}100.9 \\
2\end{array}$ & 101.18 & $\begin{array}{c}101.2 \\
2\end{array}$ & $\begin{array}{c}101.2 \\
2\end{array}$ & 100.04 & $\begin{array}{c}100.4 \\
4\end{array}$ & $\begin{array}{c}101.2 \\
8\end{array}$ & 100.07 & $\begin{array}{c}101.3 \\
8\end{array}$ & 99.87 & 99.90 \\
\hline \multicolumn{19}{|c|}{ Formulae are based on 8 cations (IMA procedure; Armbruster et al., 2006) } \\
\hline $\mathrm{Si}$ & 3.05 & 3.04 & 3.01 & 3.02 & 3.04 & 3.04 & 3.03 & 3.02 & 3.02 & 3.02 & 3.04 & 3.05 & 3.02 & 3.00 & 3.05 & 3.05 & 3.01 & 3.03 \\
\hline $\mathrm{Ti}$ & 0.02 & 0.04 & 0.01 & 0.05 & 0.03 & 0.01 & 0.04 & 0.04 & 0.01 & 0.05 & 0.02 & 0.01 & 0.04 & 0.01 & 0.01 & 0.04 & 0.01 & 0.02 \\
\hline $\mathrm{Al}$ & 2.03 & 2.10 & 2.55 & 1.93 & 2.16 & 2.46 & 1.99 & 2.05 & 2.37 & 2.02 & 2.05 & 2.40 & 2.01 & 2.23 & 2.27 & 1.89 & 2.46 & 2.22 \\
\hline $\mathrm{Fe}^{3+}$ & 0.02 & 0.19 & 0.09 & 0.00 & 0.12 & 0.00 & 0.15 & 0.32 & 0.20 & 0.00 & 0.24 & 0.12 & 0.21 & 0.18 & 0.24 & 0.16 & 0.02 & 0.36 \\
\hline $\mathrm{Fe}^{2+}$ & 0.94 & 0.73 & 0.53 & 0.99 & 0.70 & 0.56 & 0.78 & 0.61 & 0.48 & 0.93 & 0.67 & 0.49 & 0.73 & 0.65 & 0.50 & 0.87 & 0.60 & 0.46 \\
\hline
\end{tabular}

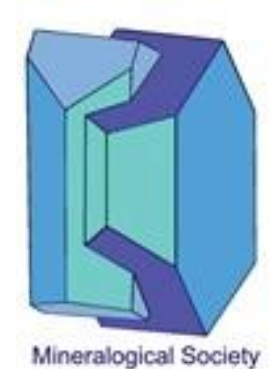

This is a 'preproof' accepted article for Mineralogical Magazine. This version may be subject to change during the production process.

DOI: $10.1180 / \mathrm{mgm} .2020 .4$ 


\begin{tabular}{|c|c|c|c|c|c|c|c|c|c|c|c|c|c|c|c|c|c|c|}
\hline $\mathrm{Mg}$ & 0.09 & 0.07 & 0.03 & 0.10 & 0.05 & 0.03 & 0.07 & 0.05 & 0.03 & 0.09 & 0.07 & 0.03 & 0.08 & 0.05 & 0.03 & 0.10 & 0.05 & 0.05 \\
\hline $\mathrm{Ca}$ & 1.05 & 1.29 & 1.48 & 1.00 & 1.34 & 1.47 & 1.26 & 1.41 & 1.54 & 1.07 & 1.35 & 1.55 & 1.27 & 1.34 & 1.54 & 1.15 & 1.39 & 1.54 \\
\hline $\mathrm{La}$ & 0.18 & 0.09 & 0.06 & 0.22 & 0.11 & 0.09 & 0.15 & 0.11 & 0.07 & 0.20 & 0.11 & 0.07 & 0.13 & 0.12 & 0.09 & 0.15 & 0.09 & 0.06 \\
\hline $\mathrm{Ce}$ & 0.37 & 0.24 & 0.13 & 0.43 & 0.25 & 0.20 & 0.32 & 0.24 & 0.16 & 0.38 & 0.25 & 0.17 & 0.29 & 0.25 & 0.16 & 0.34 & 0.19 & 0.13 \\
\hline $\operatorname{Pr}$ & 0.09 & 0.05 & 0.02 & 0.08 & 0.05 & 0.04 & 0.06 & 0.04 & 0.03 & 0.08 & 0.06 & 0.03 & 0.06 & 0.05 & 0.03 & 0.07 & 0.05 & 0.03 \\
\hline $\mathrm{Nd}$ & 0.13 & 0.13 & 0.06 & 0.13 & 0.10 & 0.06 & 0.11 & 0.08 & 0.06 & 0.12 & 0.09 & 0.06 & 0.12 & 0.09 & 0.05 & 0.12 & 0.08 & 0.07 \\
\hline $\mathrm{Sm}$ & 0.02 & 0.03 & 0.02 & 0.02 & 0.02 & 0.01 & 0.02 & 0.01 & 0.01 & 0.02 & 0.02 & 0.01 & 0.02 & 0.01 & 0.01 & 0.02 & 0.02 & 0.02 \\
\hline Th & 0.02 & 0.02 & 0.01 & 0.02 & 0.02 & 0.02 & 0.03 & 0.02 & 0.01 & 0.02 & 0.02 & 0.01 & 0.02 & 0.02 & 0.01 & 0.03 & 0.02 & 0.01 \\
\hline
\end{tabular}

Note: * total iron content given as FeO; ${ }^{* *} \mathrm{H}_{2} \mathrm{O}$ is calculated assuming $1 \mathrm{OH}$ per 8 cations; ${ }^{* * *}$ Czo - borderline Aln (BSE image in Figure 4). Chemical formulae, in atoms per formula unit (a.p.f.u.), were calculated following the IMA procedure based on 8 cations p.f.u. (Armbruster et al., 2006). The missing elements at the A-site consist of HREE and Y, as they were sought by EDS analyses and found to be not significant. The crystals used for the single crystal $X$-ray diffraction experiments are from the domains $C 1$ (i.e., crystals \#3.10, \#3.11 and \#1.10), T1 (\#5.3, \#5.5), and M2 (\#8.1) (see the CIF and Table S1). 
Table 2. Summary of the modal mineral fraction, the mineral growth-deformation relationships, and the features of allanite-(Ce) crystals $v s$. host rock matrix microstructures for the six analysed samples. Long side of the crossed polars microphotographs is $14 \mathrm{~mm}$.

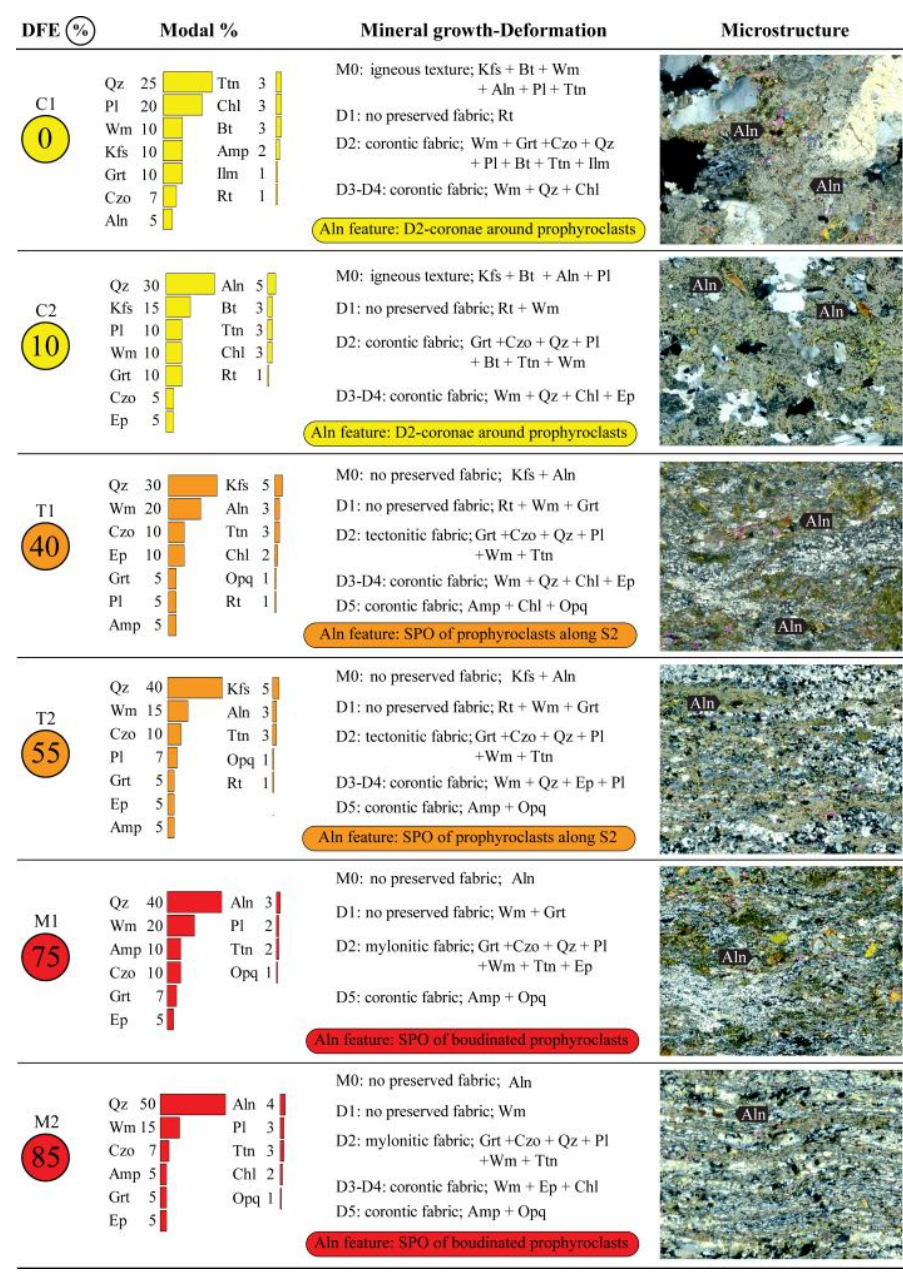

